\title{
EXTENSÃO DO PRAZO DE VALIDADE DE PATENTES FARMACEUTICAS NUMA PERSPECTIVA DE DIREITO CONSTITUCIONAL BRASILEIRO
}

\author{
EXTENSION OF THE VALIDITY PERIOD OF PHARMACEUTICAL PATENTS \\ IN A PERSPECTIVE OF BRAZILIAN CONSTITUTIONAL LAW
}

\author{
EXTENSIÓN DEL PLAZO DE VALIDEZ DE PATENTES FARMACÉUTICA EN UNA \\ PERSPECTIVA DE DERECHO CONSTITUCIONAL BRASILEÑO
}

\author{
Rafaella Dias Gonçalves \\ https://orcid.org/0000-0001-7288-3904
}

\author{
RECEBIBO 05/09/2018 \\ APROVADO 15/10/2018 \\ PUBLICADO 24/10/2018 \\ Editor Responsável: Carla Caldas \\ Método de Avaliação: Double Blind Review \\ E-ISSN: 2316-8080 \\ DOI: 10.16928
}

RESUMO

Pese a saúde ser um direito humano e encontrar-se permeada em toda a ordem jurídica internacional e na generalidade das constituições nacionais, inclusive na brasileira, não raras são as divergências existentes para a realização do direito à saúde pelos Estados. Nesse particular, a saúde no Brasil vem enfrentando questões delicadas, sobretudo no que diz respeito o acesso a medicamentos. É o caso da extensão do prazo de validade da proteção intelectual patentária inserida no ordenamento jurídico brasileiro, onde se porta como "salvaguarda" da ineficiência administrativa no exame e processamento de patentes de medicamentos de referência diante de medicamentos genéricos. A mesma, além de fortalecer à "judicialização" da saúde por ser causa da inacessibilidade de medicamentos - na sua maioria de alto custo que já deveriam estar sob o domínio público, vem causando impacto financeiro considerável aos cofres públicos brasileiro e é incompatível com a Constituição e por isso mesmo: com o privilégio temporário nela contida, a função social da propriedade, a eficiência administrativa, a segurança jurídica, o desenvolvimento tecnológico e econômico do país e especialmente para a concretização do direito à saúde. Embora, os avanços sobre o tema no Brasil ainda estejam resilientes, salientamos o valor acrescentado de medidas que já estão sendo tomadas a nível nacional, bem como através de cooperação internacional e propusemos outras alternativas para a mitigação do problema ora proposto.

PALAVRAS-CHAVE: Direito fundamental à saúde. Acesso a medicamentos. Extensão de patentes farmacêuticas.

\footnotetext{
${ }^{1}$ Mestre em Direito Constitucional (2018) pela Universidade de Coimbra (UC), Portugal. Investigadora em Direito Civil (2018) na Universidade de Sevilla (US), Espanha. Investigadora visitante no Mestrado em Análises Econômicas e Políticas Públicas (2017/2018) pela Universidade de Salamanca (USAL), Espanha. PósGraduanda em Direito Público, Direito do Trabalho e Direito Previdenciário (2014) pela Universidade Estácio de Sá (FIC) - Ceará - Brasil. Advogada inscrita na Ordem dos Advogados do Brasil (2011). Bacharela em Direito (2010) pela Universidade Estácio de Sá (FIC), Brasil | rafaelladias.adv@gmail.com
} 


\begin{abstract}
Although health is a human right and is permeated throughout the international legal order and in most national constitutions, including the Brazilian, there are many divergences in the realization of the right to health by States. In this regard, health in Brazil has been facing sensitive issues, especially regarding access to medicines. This is the case of the extension of the validity period of the patent intellectual protection inserted in the Brazilian legal system, where it behaves as a "safeguard" of administrative inefficiency in the examination and processing of patents of reference medicines against generic drugs. In addition to strengthening the "judicialization" of health because it is the cause of the inaccessibility of medicines - most of which are high costs that should already be in the public domain - has had a considerable financial impact on the Brazilian public coffers and is incompatible with the Constitution and for this very reason: with the temporary privilege contained therein, the social function of property, administrative efficiency, legal security, technological and economic development of the country and especially for the realization of the right to health. Although advances in this area in Brazil are still resilient, we emphasize the added value of measures already being taken at the national level, as well as through international cooperation, and we have proposed other alternatives to mitigate the problem proposed here.
\end{abstract}

KEYWORDS: Fundamental right to health. Access to medicines. Extension of pharmaceutical patents.

\title{
RESUMEN
}

Pese a que la salud es un derecho humano y se encuentra permeada en todo el orden jurídico internacional y en la generalidad de las constituciones nacionales, incluso en la brasileña, no raras son las divergencias existentes para la realización del derecho a la salud por los Estados. En ese particular, la salud en Brasil viene enfrentando cuestiones delicadas, sobre todo en lo que se refiere al acceso a medicamentos. Es el caso de la extensión del plazo de validez de la protección intelectual patentada insertada en el ordenamiento jurídico brasileño, donde se porta como "salvaguardia" de la ineficiencia administrativa en el examen y procesamiento de patentes de medicamentos de referencia ante medicamentos genéricos. La misma, además de fortalecer a la "judicialización" de la salud por ser causa de la inaccesibilidad de medicamentos - en su mayoría de alto costo que ya deberían estar bajo el dominio público, viene causando impacto financiero considerable a las arcas públicas brasileñas y es incompatible con la Constitución y por eso mismo: con el privilegio temporal en ella contenida, la función social de la propiedad, la eficiencia administrativa, la seguridad jurídica, el desarrollo tecnológico y económico del país y especialmente para la concreción del derecho a la salud. Aunque los avances sobre el tema en Brasil todavía son resilientes, subrayamos el valor añadido de medidas que ya se están tomando a nivel nacional, así como a través de cooperación internacional y propusimos otras alternativas para la mitigación del problema propuesto.

PALABRAS CLAVE: Derecho fundamental a la salud. Acceso a medicamentos. Extensión de patentes farmacéuticas. 


\section{INTRODUÇÃO}

O direito à saúde revela-se como uma das dimensões dos direitos fundamentais sociais de maior relevo no direito internacional dos direitos humanos, projetando-se para toda a arena global e para a generalidade dos direitos constitucionais, inclusive o brasileiro. Nessa característica irradiante está contida a universalidade e a importância que o contempla, pois é basilar para o desenvolvimento econômico, social e cultural dos povos além de constituir-se fundamental ao direito à vida, à dignidade da pessoa humana, à integridade física e psíquica e ao bem-estar individual e social.

As Constituições nacionais passaram a ser parte de um universo normativo na esfera mundial e os conflitos sociais se manifestam num mundo marcado por colisões de valores, de direitos humanos fundamentais em escala planetária. Na realidade brasileira, a saúde tem, há muito, estado no centro desses conflitos. É o caso da problemática da extensão do prazo de validade de patentes e medicamentos de referência diante de medicamentos genéricos, onde defrontam-se duas dimensões essenciais do direito à saúde. Uma que se destaca pela inovação e desenvolvimento de medicamentos pioneiros, cujo objetivo é a descoberta de entidades químicas para suprir as carências e emergências sanitárias a nível global, com o monopólio temporário de patentes, ao passo que a outra privilegia a acessibilidade a medicamentos mais baratos, sobretudo a países em desenvolvimento que possuem pouca ou nenhuma estrutura de investigação tecnológica farmacêutica.

Com a adoção da Lei de propriedade industrial 9.276/1996 brasileira que veio na sequência da incorporação do Acordo TRIPS, veremos que o monopólio desmesurado, fruto da extensão do prazo de validade de patentes contida nessa lei, alimenta a leniência da administração pública que por sua vez vem incorrendo em atrasos excessivos na análise de concessão das patentes farmacêutica, resultando no conhecido fenômeno do backlog de patentes. O backlog de patentes acrescido à extensão do prazo contido no regime de propriedade industrial brasileiro são fatores que estão sobrecarregando os cofres públicos com o pagamento vultoso de medicamentos que já deveriam estar sob o domínio público. Do mesmo modo, o alto custo de alguns medicamentos, sobretudo para tratamentos oncológicos PIDCC, Aracaju/Se, Ano VII, Volume 12 no 03, p.046 a 081 Out/2018 | www.pidcc.com.br 
não fornecidos pelo SUS, contribui para a inacessibilidade de seu consumo pela população, o que acaba por ser motor propulsor ao fenômeno da judicialização da saúde no Brasil.

Objetiva-se, pois, analisar que embora o monopólio temporário tenha guarida constitucional e a propriedade intelectual constitua incentivo ao investimento e inovação, a perenização legal de patentes consagrada no ordenamento jurídico brasileiro impede a entrada de genéricos no mercado de medicamentos que já deveriam estar sob o domínio público, contribui com o avolumar jurisprudencial por força da então judicialização da saúde e provoca consequências lesivas para o interesse público, sobretudo para a concretização das políticas públicas de saúde constitucionalmente consagradas no programa finalístico normativo-constitucional.

\section{EXTENSÃO DO PRAZO DE VALIDADE DE PATENTES FARMACEUTICAS NUMA PERSPECTIVA DE DIREITO CONSTITUCIONAL BRASILEIRO}

\subsection{Efeitos lesivos do atraso da análise de pedidos de patentes (Backlog)}

Após a assinatura do acordo TRIPS ${ }^{2}$, inegável que a atividade patentária tornou-se muito mais intensa em todo mundo ${ }^{3}$. O número de solicitações de patentes registradas nos últimos anos a nível planetário aumentou de cerca de um milhão de pedidos em 1995 para 1,91 milhões de pedidos registrados em $2008^{4}$, o que consequentemente vem demandando uma maior carga de trabalho de exame ao INAPI, a fim de que concedam patentes de forma ágil, eficiente e com qualidade.

A palavra backlog significa em tradução literal: "acumulo" ${ }^{5}$. Substantivo que se trata de um "conceito relacional"”, cujo significado só acaba por ser descoberto através da análise do

\footnotetext{
${ }^{2} \mathrm{O}$ resultado da imbricação de esforços de potências, faz nascer no âmbito da OMC o Acordo TRIPS (TradeRelated Aspects of Intellectual Property Agreement) ${ }^{2}$, que de longe representa o tratado internacional de maior abrangência no tocante a propriedade intelectual. Trade-Related Aspects of Intellectual Property Rights. (N.T.). Disponível em https://www.wto.org/english/docs_e/legal_e/27-trips.pdf Acesso em 12 de fev. de 2017.

${ }^{3}$ Dietmar Harhoff et al. demonstram que no início dos anos 1980 haviam na EPO cerca de 20 pedidos por examinador, ao passo após 1985 este número aumentou para cerca de 100 pedidos por examinador, o que responde por um acréscimo significativo de backlog no mesmo período. A complexidade dos pedidos, elevou-se de 9.84 em 1978 para 15.36 em 1998. Cf. HARHOFf, Dietmar; WAGNER, Stefan. Modeling the Duration of Patent Examination at the European Patent Office.out. 2006. Disponível em http://epub.ub.unimuenchen.de/1256/1/Harhoff_wagner_06.pdf Acesso em 19 de maio de 2018.

${ }^{4}$ WIPO, World Intellectual Property Indicators, at 34 (2010), ([hereinafter WIPO Indicators 2010]. Disponível em http://www.wipo.int/freepublications/en/intproperty/941/wipo pub 941 2010.pdf Acesso em 26 de março de 2018.

${ }^{5} \mathrm{Na}$ definição do dicionário online da Oxford (2015) backlog significa: "o acúmulo de trabalho que já deveria ter sido realizado, mas que ainda não foi concluído" (em inglês, "a quantity of work that should have been done
} 
objeto que se relaciona, dado que por óbvio, o "acúmulo" é de algo. No caso em apreço, ao relacionarmos o backlog com demora na análise de patentes, diríamos que o "acúmulo" poderia ser de patentes ou de trabalho. Assim, backlog, portanto, encerra a ideia de excesso à análise de patentes: o ponto de partida para diversos conceitos a um mesmo fim.

Sobre o que causa o backlog, não há ainda consenso em toda a literatura ${ }^{7}$. Para uns diz respeito a todos os requerimentos por examinar; para outros, o "excesso" de requerimentos foge à capacidade do INAPI. Ainda, há autores que evidenciam a preocupação mundial sobre o tema, analisando especialmente a questão também à luz do Acordo TRIPS, vindo a concluir que são inúmeros os fatores que contribuem para esses exames prolongados, entre eles: o número de pedidos de patentes, a complexidade das tecnologias envolvidas, falta de recursos suficientes e outros ${ }^{8}$.

A sobrecarga de trabalho também pode limitar a realização de um exame de qualidade ${ }^{9}$. Аввотт (2004) ${ }^{10}$ em pesquisa realizada pelo sindicato europeu de examinadores de patentes, concluiu que a referida sobrecarga exigida pelos gestores do EPO impedia de os mesmos realizarem um trabalho de qualidade estabelecida pela Convenção sobre a Patente Europeia. Para RAMADA (2010) ${ }^{11}$ parte do fenômeno do backlog é resultado da estratégia de empresas que protocolizam múltiplos requerimentos de patente ou modelo de utilidade, com o objetivo de obter proteção decorrente de privilégio, cobrar preços mais altos para seus produtos (pelo status de produto com patente pendente) e criar monopólios, mesmo que para requerimentos

already, but has not yet been done"). OXFORD. Oxford learners dictionary [online], 2018. Disponível em: http://www.oxfordlearners dictionaries.com/us/definition/english/backlog?q=backlog Acesso em: 9 mar. 2018.

${ }^{6} \mathrm{O}$ termo "Conceito relacional" é extraído do estudo sobre Compliance que em sentido literal quer dizer "estar em conformidade" e também demanda um conceito relacional, na análise do objeto que se relaciona. Para maiores desenvolvimentos, ver: SARLET, Ingo Wolgang e SAAVEDRA, Giovani Agostini - Judicialização, Reserva do Possivel e Compliance na Área da Saúde -, R. Dir. Gar. Fund, Vitória, v. 18, n.1, 2017, p. 257-282, apud RотsсH, Thomas. Criminal Compliance. In: Zeitschrift für Internationale Strafrechtsdogmatik. Ausgabe 10/2010, 5. Jahrgang, P. 614 e ss.

${ }^{7}$ Consoante Mitra Kahn et. al., um estudo interdisciplinar elaborado pelo Escritório de Propriedade Intelectual do Reino Unido (em inglês, United Kingdom Intellectual Property Office - UKIPO) e do Escritório de Patentes e Propriedade Industrial dos Estados Unidos (em inglês, United States Patentand Trademark Office - USPTO, o conceito de backlog não é bem definido.Cf. Mitra-KAHN, Benjamim et al. Patent backlogs, inventories, and pendency: an international framework. Reino Unido: Escritório de Propriedade Intelectual, 2013. p. 134.

${ }^{8}$ Cf. Hoss, E. (2012). Delays in Patent Examination and their implications under the TRIPS Agreement. Munich Intellectual Property Law Center. MIPLC Master Thesis Series (2010/11), 2012. p. 12.

${ }^{9}$ Cf. KING, John L. Patent examination procedures and patent quality. In: COHEN, W. M., MERRILL, S. A. (Eds). Patents in Knowledge-Based Economy. Washington: National Academies Press, 2003.

${ }^{10} \mathrm{Cf}$. Аввотт, Alison. Pressured staff 'lose faith'in patent quality. Nature: International Weekly Journal of Science, p. 429-493, 2004.

${ }^{11}$ Cf. RAMADA, Paula. Economic implications of global patent backlogs. Palestra no Escritório de Propriedade Intelectual do Reino Unido (United Kingdom Intellectual Property Office - UKIPO), 10 mar. 2010. Disponível em: http://www.ipo.gov.uk/pro-types/propatent/p-policy/p-policy-backlog/p-policy-econ.htm Acesso em: 14 out. 2017.

PIDCC, Aracaju/Se, Ano VII, Volume 12 no 03, p.046 a 081 Out/2018 | www.pidcc.com.br 
de criações não passíveis de obter patente (isto é, requerimentos não patenteáveis, as chamadas non patentable applications $)^{12}$.

Um estudo estabulado pela London Economics, em 2010, doravante denominado Patent backlogs and mutual recognition ${ }^{13}$, feito sob pedido do INAPI britânico UKIPO, estima que cada ano de proteção provisória (pendency) no Escritório Trilateral de Patentes ${ }^{14}$ resulta em impacto negativo na economia global de aproximadamente $£ 7,6$ bilhões, dos quais $£ 6$ bilhões referentes à redução do incentivo à inovação; $£ 359$ milhões, sobre os requerimentos não patenteáveis adicionais e $£ 1,2$ bilhão, resultante do poder monopolístico relativo a requerimentos não patenteáveis. Dentre as várias conclusões do estudo britânico, a considerada mais nociva, diz respeito ao impacto negativo nos agentes econômicos decorrente do backlog e da consequente "incerteza" sobre a possibilidade de explorar a tecnologia, na patente que se almeja.

Pese os muitos fatores sobre o backlog, o que verdadeiramente importa é que a demora na análise de patentes, no setor farmacêutico - pela complexidade da área tecnológica ${ }^{15}$, e pelas consequências vitais que pode acarretar em se tratando de medicamentos e direito à saúde, têm sido demasiadamente preocupante para vários atores em jogo: os titulares das patentes, os investidores, os usuários de medicamentos (sejam eles consumidores finais ou governo $)^{16}$. Ainda, além gerar consequências deletérias para os cofres públicos, os atrasos

\footnotetext{
${ }^{12}$ Quanto às estratégias de monopólio, Chalermsak Kittitrakul, coordenador para o acesso a campanhas de medicamentos a Fundação de Acesso AIDS (em inglês, AIDS ACCESS Foundation), na Tailândia, afirma que desde que a proteção de patente começa quando um pedido é apresentado, as empresas multinacionais freqüentemente enviam avisos legais ameaçadores a empresas de genéricos que tentam produzir uma droga semelhante, mesmo que ainda não esteja claro que a patente será concedida, disse ele. As empresas também aproveitam a lacuna no processo de exame de patentes, ele disse: $\mathrm{O}$ estudo, sobre patentes evergreening em medicamentos realizados por uma equipe acadêmica cobrindo patentes e pedidos de patentes em 2000-2010, mostrou que a maioria dos pedidos de exame passo inovador para patentes de drogas são submetidos ao DIP no quarto e quinto ano. "Big Pharma não tem nada a perder, fazendo uso da lacuna jurídica em combinação com o uso de cartas ameaçadoras para as empresas de genéricos ou até mesmo para os hospitais considerando a possibilidade de comprar os genéricos". Desse modo, fabricantes de medicamentos locais recuam em vez de arriscar a possibilidade de ter que pagar uma indemnização se a patente é concedida. Disponivel em: http://www.ip-watch.org/2018/05/18/patent-backlogs-fuel-efforts-extend-pharma-patent-terms-thailand-brazil aidsactivists-say/ Acesso em 16 de março de 2018.

${ }^{13}$ LONDON ECONOMS. Patent backlogs and mutual recognition. Reino Unido: Escritório de Propriedade

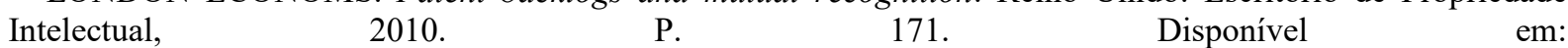
https://www.gov.uk/government/uploads/system/uploads/attachment_data/file/328678/p-backlog-report.pdf Acesso em: 15 fev. 2018.

${ }^{14} \mathrm{O}$ European Patent Office (EPO), o United States Patentand Trademark Office (USPTO) e o Japanese Patent Office (JPO) compreendem o Escritório Trilateral de Patentes (Trilateral Patent Office).

${ }^{15} \mathrm{O}$ aspecto determinante para um maior backlog é a complexidade da área tecnológica, como se observa para pedidos de patentes nas áreas de biotecnologia, fármacos e semicondutores. Cf. SAMPAIO, Gilberto, BORCHIVER, Suzana. Critérios para avaliação dos sistemas patentários, Revista da ABPI, Ro de Janeiro. jan.fev. 2009. p.3041.

${ }^{16}$ Ver JÚNIOR, Sílvio Sobral Garcez e MOREIRA, Jane de Jesus da Silveira, O backlog de patentes no Brasil: o direito à razoável duração do procedimento administrativo. REVISTA DIREITO GV | SÃO PAULO | V. 13 N. 1 | 171-203 | JAN-ABR 2017. p. 173.
}

PIDCC, Aracaju/Se, Ano VII, Volume 12 no 03, p.046 a 081 Out/2018 | www.pidcc.com.br 
impedem a concorrência de genéricos e inibem a atividade de $\mathrm{P} \& \mathrm{D}$ da indústria farmacêutica, devido à incerteza decorrente da proteção provisória reconhecida a partir do requerimento $(\text { pendency })^{17}$.

\subsubsection{Backlog e o INPI}

O responsável pela concessão de patentes no Brasil é o INPI ${ }^{18}$, que possui personalidade jurídica de autarquia federal vinculada ao Ministério da Indústria, Comércio Exterior e Serviços. O tempo de análise pela autarquia para concessão de patentes no Brasil tem aumentado de forma preocupante, saltando de 6,8 anos, em 2003, para 10,8 anos (mais de 120 meses), em $2013^{19}$. Atualmente, o Brasil lidera o ranking mundial no atraso de concessão de patentes, ficando atrás, inclusive, de países como a Índia, República Tcheca e Vietnã: “[o] tempo médio de decisão final ultrapassou 50 meses no Brasil $(95,4)$, Índia (84), República Tcheca (53) e Vietnã $(51,5)$ ”20. Já países como Japão, Canadá e EUA tiveram o tempo reduzido de pendência nos últimos anos: “[o] Japão teve a redução mais acentuada no tempo de pendência da primeira ação de escritório, de 25,9 meses em 2011 para 9,5 meses em 2016; Canadá e os $E U A^{21}$ também diminuíram o pendency de ação no mesmo período" 22 .

\footnotetext{
${ }^{17}$ No que diz respeito aos requerentes, os atrasos excessivos criam um grande problema para eles, no sentido de que dificultam a tomada de decisões estratégicas sem saber se lhes será concedido um direito exclusivo ou não. Além disso, do ponto de vista internacional, os atrasos de um único escritório de patentes poderiam tornar toda a proteção jurídica internacional dos solicitantes, de certa forma, incerta e, portanto, poderia atrasar as estratégias de mercado internacional dos solicitantes. Cf. JENSEN Paul H. et al, Application Pendency Times and Outcomes across Four Patent Offices 6 (Melbourne Institute Working Paper Series 2008), Disponível em: http://melbourneinstitute.com/downloads/working paper_series/wp2008n06.pdf Acesso em 05 de outubro de 2017.

18 “[o] Instituto Nacional da Propriedade Industrial (INPI) é uma autarquia federal vinculada ao Ministério da Indústria, Comércio Exterior e Serviços, responsável pelo aperfeiçoamento, disseminação e gestão do sistema brasileiro de concessão e garantia de direitos de propriedade intelectual para a indústria. Entre os serviços do INPI, estão os registros de marcas, desenhos industriais, indicações geográficas, programas de computador e topografias de circuitos integrados, as concessões de patentes e as averbações de contratos de franquia e das distintas modalidades de transferência de tecnologia. Na economia do conhecimento, estes direitos se transformam em diferenciais competitivos, estimulando o surgimento constante de novas identidades e soluções técnicas. O INPI conta com uma nova estrutura regimental, que foi estabelecida pelo Decreto $\mathrm{n}^{\circ} 8.854$, de 22 de setembro de 2016". Disponível em: http://www.inpi.gov.br/sobre/estrutura Acesso em: 17 de maio de 2017.

19 Ver JÚNIOR, Sílvio et al. op. cit. p. 182.

20 " [t] the average time for final decision exceeded 50 months in Brazil (95.4), India (84), the Czech Republic (53) and Viet Nam (51.5)": WIPO (2017). World Intellectual Property Indicators 2017. Geneva: World Intellectual Property Organization:

${ }^{21}$ Nos Estados Unidos, onde existem dispositivos legais compensatórios por atrasos administrativos na análise dos pedidos, calcula-se que em 2013 foram gastos US\$ 19 bilhões desnecessariamente com 13 medicamentos. Cf. GAUDRY KS, CUMMINGS DE. Patent office backlog adds billons to national drug expenditure.Nat Biotechnol 2014; v. 32. p. 7. Disponível em: https://www.nature.com/articles/nbt.2894 Acesso em 02 de fevereiro de 2018.

${ }^{22}$ Idem.
} 
Dentre os motivos que podem justificar o atraso pelo INPI é que o mesmo não conta com servidores suficientes para análise e tramitação dos processos administrativos ${ }^{23}$. Outra questão que agravou esse quadro se deu com a celeuma sobre a delimitação da competência técnica do INPI e da Agência Nacional de Vigilância Sanitária (ANVISA), a qual se perdurou durante muito tempo na seara administrativa, conduzindo a uma duplicidade na averiguação dos requisitos de patenteabilidade ${ }^{24}$, através da "anuência prévia" das patentes pela análise discricionária da ANVISA ${ }^{25}$. Contudo, tal inconsistência já foi superada, não cabendo mais a referida anuência prévia à ANVISA, com a assinatura da Portaria Conjunta no 1 , de 12 de abril de 2017, entre a ANVISA e o INPI ${ }^{26}$.

Nesse caso, o ônus pela ineficiência estatal é transferido aos concorrentes e em particular para sociedade brasileira no que toca especialmente o acesso a medicamentos: o Estado não assume a responsabilidade objetiva prevista no (art. $37, \S 6^{\circ}$, da $\left.\mathrm{CFB}\right)^{27}$, mas acresce em favor do titular das patentes. A demora sistemática na análise do pedido de patentes, portanto, alimentada e legitimada pelo parágrafo único do art. 40 da Lei 9.279/1996, é altamente lesiva ao interesse público e à Constituição como se verá adiante.

\section{PRIVILÉgio TEMPORÁRIO DE PATENTE E FUNÇÃo SOCIAL DA PROPRIEDADE}

${ }^{23}$ Cf. JANNUZZI, AHL, VASCONCELlos AG. Um estudo sobre a concessão de patentes de medicamentos no Brasil e suas implicações para a continuidade do êxito na política de medicamentos genéricos. In: Anais do XV Congresso Latino-americano de Gestão Tecnológica. Lisboa: Centro de Estudos em Inovação, Tecnologia e Políticas de Desenvolvimento; 2013. p. 3198-214.

${ }^{24}$ Idem.

${ }^{25} \mathrm{O}$ autor Denis Barbosa já havia tido oportunidade de manifestar-se contra a anuência prévia da ANVISA para análise de patentes, inclusive considerando inconstitucional. Segundo ele: "[o] direito de pedir patente (e de obtê-la, uma vez verificados os requisitos legais) tem fundamento constitucional; ele não pode ser afetado por qualquer norma que condicione a concessão do direito ao assentimento da União. O procedimento de concessão de patentes é vinculado, e não dá ensejo à manifestação volitiva da ANVISA ou de qualquer ente público". Para maiores desenvolvimentos, ver: BARBOSA, Denis. Uma introdução à propriedade intelectual, 2a. Edição, Lumen Juris, 2003, p. 442.

${ }^{26}$ BRASIL. ANVISA. Portaria Conjunta no 1, de 12 de abril de 2017. Regulamenta os procedimentos para a aplicação do artigo 229-C da Lei no 9.279, de 14 de maio de 1996, acrescido pela Lei no 10.196, de 14 de fevereiro de 2001, e dá outras providências. Diário Oficial da União 2017.

27 "Art. 37. A administração pública direta e indireta de qualquer dos Poderes da União, dos Estados, do Distrito Federal e dos Municípios obedecerá aos princípios de legalidade, impessoalidade, moralidade, publicidade e eficiência" [...] $\S 6^{\circ}$ : As pessoas jurídicas de direito público e as de direito privado prestadoras de serviços públicos responderão pelos danos que seus agentes, nessa qualidade, causarem a terceiros, assegurado o direito de regresso contra o responsável nos casos de dolo ou culpa. Ver: BRASIL. Constituição Federal de 1988. Promulgada em 5 de outubro de 1988. Disponível em http://www.planalto.gov.br/ccivil 03/constituicao/constituicaocompilado.htm Acesso em 11 de março de 2018. 
A patente é um catalisador da atividade econômica tecnológica, mediante um direito temporário, cuja previsão está contida na Constituição como garantia fundamental no Artigo $5^{\circ}$, XXIX, a ver:

Art. $5^{\circ}$. Todos são iguais perante a lei, sem distinção de qualquer natureza, garantindo-se aos brasileiros e aos estrangeiros residentes no País a inviolabilidade do direito à vida, à liberdade, à igualdade, à segurança e à propriedade, nos termos seguintes:

[...] XXIX - a lei assegurará aos autores de inventos industriais privilégio temporário para sua utilização, bem como proteção às criações industriais, à propriedade das marcas, aos nomes de empresas e a outros signos distintivos, tendo em vista o interesse social e o desenvolvimento tecnológico e econômico do País; $[\ldots]$.

Para SILVA $(2010)^{28}$, pese a proteção à propriedade intelectual esteja localizada entre as garantas individuais, a mesma não possui natureza de direito fundamental e portanto depende de legislação ordinária, tratando-se de norma com eficácia limitada. Ainda assim, a proteção temporária à propriedade intelectual é assegurada constitucionalmente, através de lei, desde que observadas sua função social (interesse social) e pelo desenvolvimento econômico do país, consoante cláusula finalística do supracitado artigo. BARBOSA (2009) ${ }^{29}$ pondera que: [a] cláusula final, novidade do texto atual, torna claro que os direitos relativos à Propriedade Industrial não derivam diretamente da Constituição brasileira de 1988, mas de lei ordinária; e tal lei só será constitucional na proporção em que atender aos seguintes objetivos: a) visar ao interesse social do país; b) favorecer o desenvolvimento tecnológico do país; c) favorecer o desenvolvimento econômico do país. Desse modo, o relevante interesse público envolvido na parte in fine do dispositivo constitucional, impõe que o direito exclusivo só seja concedido mediante a presença desses objetivos legais e constitucionais.

A "patente é também um instrumento de política de empresa, visto que o direito exclusivo confere ao titular da patente a oportunidade de explorar a invenção, sem concorrência, durante um período determinado; ela serve, também, como meio de reservar o mercado de um determinado produto" ${ }^{30}$. Desse modo, o privilégio de exploração patentária pode ser utilizado como instrumento de reserva de mercado, limitando a concorrência o que pode provocar o efeito inverso: de obstáculo ao desenvolvimento tecnológico.

\footnotetext{
${ }^{28}$ Cf. Silva, José Afonso da. Comentário contextual à Constituição. 7. ed. São Paulo: Malheiros, 2010, p. 127.

${ }^{29}$ Cf. BarbosA, Denis Borges. A propriedade intelectual no século XXI: estudos de Direito. Rio de Janeiro: Lumen Juris, 2009, p. 663.

${ }^{30}$ Cf. LABrUnie, Jacques. Direito de patentes: condições legais de obtenção e nulidades. Barueri, 2006 , p. 24. 
A despeito da relevância do sistema de proteção patentária com vistas ao progresso tecnológico e em combate à referida "reserva de mercado", o princípio da função social da propriedade ao sistema de patentes se faz codição sine qua non e está prevista na constituição, no art. 5', XXIII: "a propriedade atenderá a sua função social”. A jurista brasileira PIOVESAN $(2007)^{31}$, em estudo sobre a relação entre direitos humanos e propriedade intelectual, concluiu que a proteção da propriedade intelectual possui limites e que deve ser ponderada conforme sua função social, em razão de seu impacto nos direitos sociais, econômicos e culturais. Isso equivale a uma "relativização" da propriedade, na medida que a norma constitucional não somente busca garantir privilégio de exploração de propriedade intelectual, mas também assegura aos demais atores, consumidores e investidores, que findo o decurso de prazo legal da proteção, o monopólio de exploração da invenção industrial será extinto $^{32}$.

Ao legislador ordinário cabe a ponderação constitucionalmente equilibrada entre os direitos fundamentais e o interesse coletivo, principalmente no caso das patentes farmacêuticas, cuja proteção resvala no $\mathrm{P} \& \mathrm{D}$ da indústria no setor que aposte tanto no desenvolvimento de medicamentos inovadores quanto na justa concorrência com a abertura à indústria de genéricos ${ }^{33}$. O direito constitucional não faz e nem pode fazer privilégios a um ou

\footnotetext{
31 "Na visão do Comitê os próprios delineamentos conceituais do direito à propriedade intelectual hão de ser redefinidos considerando a necessária proteção dos direitos sociais, econômicos e culturais. Isto é, à luz dos direitos humanos, o direito à propriedade intelectual cumpre uma função social, que não pode ser obstada em virtude de uma concepção privatista deste direito que eleja a preponderância incondicional dos direitos do autor em detrimento da implementação dos direitos sociais, como o são, por exemplo, à saúde, à educação e à alimentação. Observe-se ainda que, via de regra, o conflito não envolve os direitos do autor versus os direitos sociais de toda uma coletividade; mas, sim, o conflito entre os direitos de exploração comercial (por vezes abusiva) e os direitos sociais da coletividade. [...] Extrai-se, assim, o dever dos Estados de alcançar um balanço adequado entre a proteção efetiva dos direitos do autor/inventor (lembrando que, via de regra, quem acaba por prejudicar os interesses sociais e os direitos humanos são os detentores dos direitos de exploração comercial de determinada obra ou invento) e a proteção dos direitos sociais à educação, alimentação e saúde, bem como aos direitos culturais e de desfrute dos progressos científicos. Nesta ponderação de bens, o direito à proteção da propriedade intelectual não deve ser considerado ilimitado ou absoluto, na medida em que a propriedade intelectual tem uma função social. Os regimes jurídicos de proteção da propriedade intelectual devem ser analisados sob a perspectiva de seu impacto no campo dos direitos humanos". Cf. PIOvESAN, Flávia. (2007) Direitos humanos e propriedade intelectual. 2007, p. 20- 21. Disponível em: Acesso em:http://bibliotecadigital.fgv.br/dspace/bitstream/handle/10438/2665/CL01\%20\%20Flavia\%20Piovesan\%20Di reitoshumanosepropriedadeintelectual.pdf? sequence $=3$ Acesso em: 03 de jan. 2018.

32 Para maiores desenvolvimentos sobre a relativização da propriedade, com privilégios temporários, cf. BASSO, Maristela. Comentário ao art. $5^{\circ}$, XXIX. in: CANotilho, J.J. Gomes; Mendes, Gilmar F.; SARLET, Ingo W.; StRECK, Lenio L.(coords.). Comentários à Constituição do Brasil. São Paulo: Saraiva/Almedina, 2013, p. 335.

${ }^{33}$ Compreende-se que o sistema de patentes apresenta-se como o mais eficaz no equilíbrio entre os interesses em questão: por um lado, procura responder aos interesses do inventor no sentido em que atribui um direito de exclusivo de exploração do bem objecto de patente e, por outro, busca responder aos interesses da comunidade em virtude de exigir, ao titular desse direito privativo, a divulgação da tecnologia patenteada e respectivos meios de execução ao garantir o seu livre acesso no termo do período de proteç̧ão. Está em causa a concessão ao inventor de um monopólio legal, durante um determinado lapso de tempo, findo o qual a invenção cai no domínio público. Para maiores desenvolvimentos, cf: MARQUES, João Paulo Remédio (II), Medicamentos Versus Patentes - Estudos de Propriedade Industrial, $1^{\text {a }}$ ed., Coimbra, Coimbra Editora, 2008.
} 
ao outro, mas certo é que o acesso a medicamentos à luz da proteção constitucional da propriedade intelectual, somente terá sua função social efetivada se por fim objetivar à promoção do direito fundamental à saúde e o fomento à inovação no setor no país.

É com base nesse pano de fundo que a Lei n 9.279/96 vigora no Brasil, vindo a regular direitos e obrigações sobre a propriedade industrial. A mesma, além de tornar plena a norma constitucional de eficácia limitada no art. $5^{\circ}$. XXIX, foi criada com o objetivo de adaptar-se às regras de propriedade intelectual (latu sensu) do Acordo TRIPS ao abrigo da OMC, com o fito de regulamentar os direitos relativos à propriedade industrial (strictu sensu), exceto as questões relativas aos direitos de autor ${ }^{34}$. E mais particularmente, por força do princípio da não-discriminação (art. 27\%1 do Acordo TRIPS), o Brasil assumiu o compromisso internacional e adaptou sua legislação para reconhecer, dentre outros, produtos farmacêuticos patenteáveis no ordenamento jurídico brasileiro, observadas as situações excepcionais no período de transição ${ }^{35}$. Com efeito, os direitos exclusivos do titular da patente foram consagrados no artigo 42, inciso I, da LPI onde dispõe que: “[a] patente confere ao seu titular

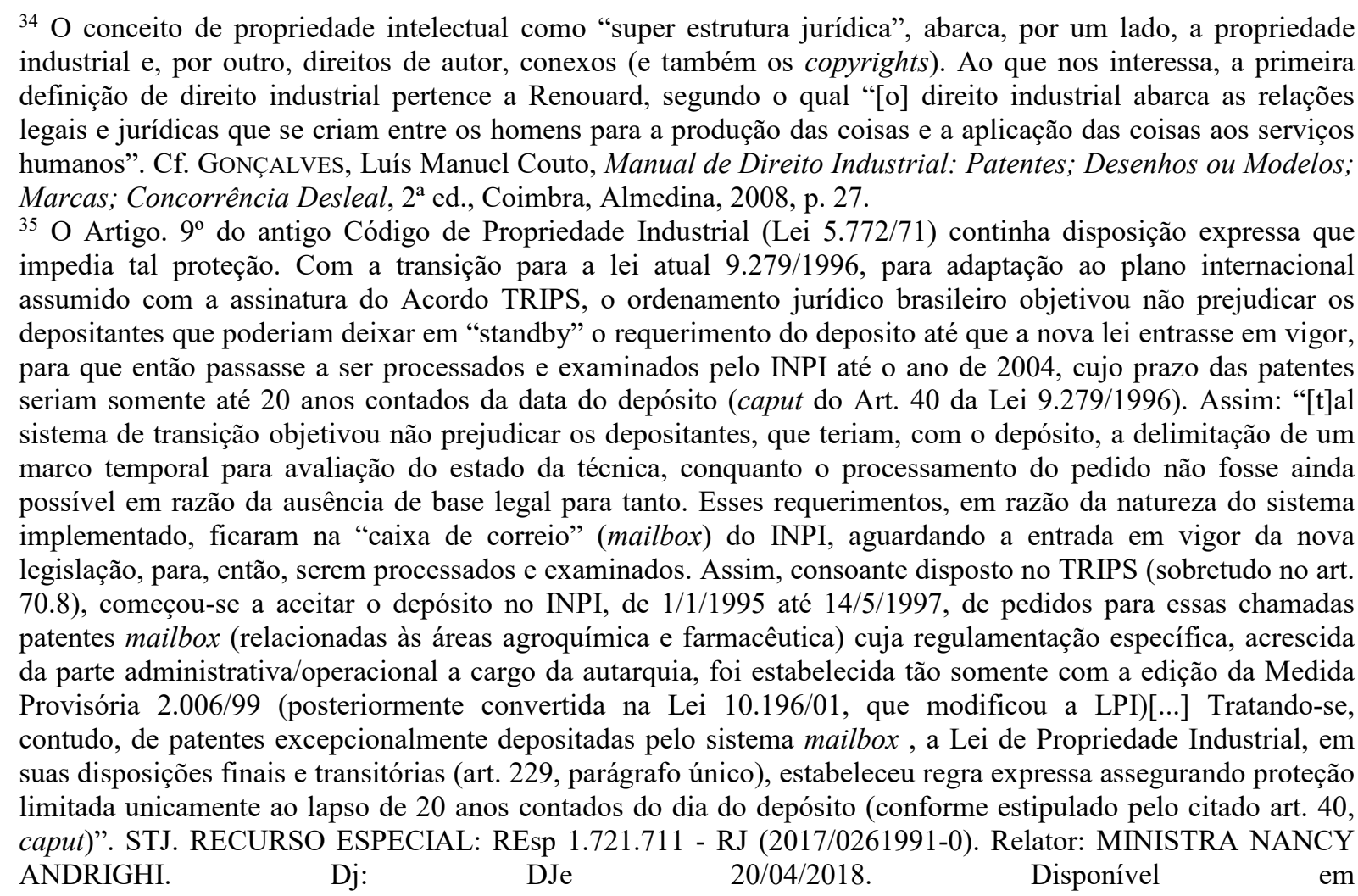
ANDRIGHI. Dj: DJe $\quad$ DJ
http://www.sti.jus.br/SCON/jurisprudencia/toc.jsp?livre=RESp+1721711\&\&b=ACOR\&thesaurus=JURIDICO\& p=true Acesso em 15 de maio de 2018.

PIDCC, Aracaju/Se, Ano VII, Volume 12 no 03, p.046 a 081 Out/2018 | www.pidcc.com.br 
o direito de impedir terceiro sem o seu consentimento, de produzir, usar, colocar à venda, vender ou importar com estes propósitos um [...] produto objeto de patente" 36 .

Indubitavelmente, a norma assume um relevo importante no panorama atual, em que se reconhece a patenteabilidade dos produtos farmacêuticos no Brasil, sendo relevante a proteção constitucional ao esforço individual da criação, por meio das patentes ${ }^{37}$. Ao mesmo tempo, verifica-se que após o Brasil começar a conceder patentes de produtos e processos farmacêuticos, o preço dos fármacos se elevou demasiadamente ${ }^{38}$. Esse fato foi motor propulsor para que em 1999, o Brasil adotasse a "Lei dos Genéricos", Lei 9.787/199939.

Desde então, o interesse social em acessar as patentes farmacêuticas através de medicamentos genéricos ainda encontra barreiras e uma delas repousa na prorrogação da vigência das patentes prevista no parágrafo único do artigo 40 da LPI. Tais práticas são conhecidas pela literatura como evergreening ou perenização, que permitem o monopólio de uma patente durar muito mais tempo, talvez até indefinidamente, atrasando a entrada de genéricos no mercado ${ }^{40}$.

\subsection{O parágrafo único do Artigo 40 da Lei 9.279/1996 (perenização legal)}

O parágrafo único do art. 40 da LPI prevê um prazo de vigência mínimo a contar da concessão da patente, a ver:

\footnotetext{
Artigo 40: A patente de invenção vigorará pelo prazo de 20 (vinte) anos e a de modelo de utilidade pelo prazo 15 (quinze) anos contados da data de depósito.

Parágrafo único. O prazo de vigência não será inferior a 10 (dez) anos para a patente de invenção e a 7 (sete) anos para a patente de modelo de utilidade, a contar da data de concessão, ressalvada a hipótese de o INPI estar impedido de proceder ao exame de mérito do pedido, por pendência judicial comprovada ou por motivo de força maior.
}

Da leitura se extrai que aplicada a exceção prevista nesse parágrafo, será garantido ao titular uma vigência que corresponda a um mínimo de 10 anos para a patente de invenção e 7

\footnotetext{
${ }^{36}$ Vide supra nota 2, art. 42, I.

${ }^{37}$ Cf. MAChado, J.E.M \& Raposo, V.L. (2010). Direito à Saúde e qualidade dos medicamentos, Almedina, Coimbra, 2010.

${ }^{38}$ Cf. KWEITEL, J. \& REIS, R. (2007) A primeira licença compulsória de medicamento na América Latina. International Centre for Trade and Sustainable Development - ICTSD. Pontes, v. 3, (3), junho de 2007.

${ }^{39}$ BRASIL. LEI No 9.787, DE 10 DE FEVEREIRO DE 1999. Altera a Lei no 6.360, de 23 de setembro de 1976, que dispõe sobre a vigilância sanitária, estabelece o medicamento genérico, dispõe sobre a utilização de nomes genéricos em produtos farmacêuticos e dá outras providências. Brasília, DF. Disponível em http://www.planalto.gov.br/ccivil 03/Leis/L9787.htm Acesso em 20 de maio de 2017.

${ }^{40}$ Cf. STIMAC, A. (2016). The Trans-Pacific Partnership: The Death-Knell of Generic Pharmaceuticals? 49 Vand. J. Transnat'l L. 853 (University Law School, Vanderbilt Journal of Transnational Law), 2016, p. 6.
} 
ao de modelo de utilidade, a contar da concessão da patente, prevista no art. $38 \S 3^{\circ}$, o que poderá resultar em uma proteção de mais de 20 anos. A dita extensão, inicialmente, foi incluída na legislação brasileira para ser uma exceção ao regime de vigência geral (prazo vintenário $)^{41}$. Todavia, a exceção tornou-se regra $^{42} \mathrm{em}$ : $38 \%$ das cartas-patentes expedidas para pedidos depositados em 1997, 85,5\% para pedidos depositados em 1998 e praticamente $100 \%$ das patentes concedidas para medicamentos depositadas no Brasil após 199943".

O crescimento exponencial da extensão de patentes por força legal, reflete-se na alarmante situação atual que leva o Brasil a liderar o ranking mundial de atraso na análise de patentes pela administração. E, ainda que por mora do INPI, não constitui instrumento compatível com a Constituição, conforme prelaciona João da Gama Cerqueira:

A prorrogação do prazo de duração do privilégio é medida que não encontra nenhuma justificativa e que só poderá dar lugar a abusos e injustiças. (...) Não receamos errar afirmando que os interesses nacionais e os interesses da coletividade não se conciliam nunca com a prorrogação do prazo dos privilégios, exigindo, ao contrário, a sua extinção no prazo normal. De fato, como pode a Nação ou a coletividade ter interesse na permanência de um privilégio que cerceia a liberdade de todos e cuja exploração exclusiva só ao seu concessionário traz benefício? Aliás, a incoerência da lei mais se patenteia quando faz depender a prorrogação do prazo de "pedido devidamente comprovado", pois esse pedido somente poderá ser feito pelo único interessado no prolongamento do privilégio, isto é, pelo concessionário, o qual representa seus interesses pessoais e não os interesses nacionais ou os da coletividade (CERQUEIRA, 2010, 159) ${ }^{44}$

\footnotetext{
${ }^{41}$ Mesmo assim, os fundamentos da prorrogação excepcional careceram de iluminação judicial ao longo dos anos, na medida em que a interpretação distorcida poderia ter conduzido aos caos monopolista de muitos atores da indústria farmacêutica que tentaram aproveitar a medida expansiva para amplicar a proteção de privilégio, sem que houvesse precedentes para isso. É o caso de patentes "caixa de correio" (em inglês mailbox). O Artigo 229-B prevê uma regra transitória especial em que os pedidos de patentes mailbox (antigas patentes que tiverem o privilegio de serem processadas e examinadas pelo INPI, com a vigência da nova lei 9.179/1996) deveriam ser examinadas pelo órgão administrativo até 31/12/2004. Mas, algumas patentes somente foram concedidas após esse prazo, perdendo o objeto em razão do lapso temporal, o que motivou uma série de ações pelos titulares na tentativa de estender o prazo de validade de patentes ao abrigo do parágrafo único, do Artigo 40 da LPI. Outrossim, em decisão recentíssima de 2018, o STJ entendeu que: "[v]ale dizer, o fato de o texto do art. 229, da LPI dispor que referido prazo de vigência está somente "limitado" àquele previsto no "caput" do artigo 40 afasta, como corolário, a incidência do prazo do respectivo parágrafo único (10 anos contados da concessão). Este dispositivo legal (art. 40, parágrafo único, da LPI), ademais, não deve incidir sobre a presente hipótese fática por estar inserido em capítulo da lei que versa sobre regras gerais aplicáveis ao sistema ordinário de patentes, não podendo irradiar efeitos sobre matéria a qual foi conferido tratamento especial pela mesma lei (sistema transitório mailbox)". Para maiores desenvolvimentos, vide supra nota 263.

${ }^{42}$ Como bem observado pela jurisprudência, "se lembrarmos que em relação aos inventos, o domínio público é a regra e a proteção, exceção, sempre condicionada a inúmeros fatores e por prazo sempre limitado" Cf. TRF- $2^{\mathrm{a}}$ Região, $2^{\mathrm{a}}$ Turma Especializada. AC 2005.51.01.534005-6. Des. André Fontes. DJ 11.12.2007.

${ }^{43}$ Ver JanNuZZI AHL, VASCONCELlos AG. Op. Cit. p. 214.

${ }^{44}$ Cf. Cerqueira, João da Gama. Tratado da Propriedade Industrial, $3^{\mathrm{a}}$. Edição, anotado por Newton Silveira e Denis Borges Barbosa, Lumen Juris, 2010, vol. II, no. 159.
} 
Há uma sinestesia deletéria entre o atraso do INPI e a sua salvaguarda com a prorrogação da validade de patentes que deveria ser combatida com eficiência e não com uma “compensação perene" suportada pela sociedade. Tal, viola a função social da propriedade, além de divergir com o interesse público. Ademais, em detrimento desse último há uma "camada" que se beneficia com a famigerada perenização, pois a par da "exceção" do artigo 40, a LPI brasileira já protege os interesses do requerente da patente muito antes da mesma ser concedida (se for aprovada) e cair no domínio público nos Artigos 42 e 44. Então, estaríamos diante de um bis in idem compensatório em favor da big farma?

\subsection{Natureza compensatória da perenização legal}

Na maioria dos países, o backlog de patentes é combatido com aumento de eficiência e não com aumento de prazos, cujo prejuízo resulta aos competidores e para toda a sociedade civil, ou seja: “o prazo mínimo a partir da concessão da patente é dispositivo especial na nossa legislação, não encontrado correlato em vários países do mundo ${ }^{45}$ ". A esse despeito, no dizer de BARBOSA $(2015)^{46}$, apenas nos EUA existe a hipótese de "prazo variável” por backlog. A legislação americana possui a hipótese de prazo extensivo compensatório de no máximo cinco anos em caso de atraso administrativo pelo USPTO ${ }^{47}$. Assim, "a Lei de Patentes prevê um ajustamento (extensão) de duração da patente caso o escritório de patentes (USPTO) incorra em atrasos durante o exame de patentes ${ }^{48}$ ". Ressalte-se que a despeito de seu exemplo, os EUA tentaram exigir a modificação da legislação interna de alguns países para incluir a extensão do prazo do backlog (prazo variável) através de alguns acordos bilaterais de livrecomércio firmados com determinados países em desenvolvimento ${ }^{49}$.

\footnotetext{
${ }^{45}$ [Nota do Original] TRF-2a REGIÃO: AMS 2005.51.01.507058-6, JC Márcia Helena Nunes, DJ 12.12.2008. Nesse caso, o Tribunal também entendeu que o retardo da concessão da patente resulta de pleito judicial ou outra causa externa ao funcionamento da autarquia, não cabe o aumento de prazo: "A generosidade, entretanto, encontra limites na demora da concessão por motivos alheios à ingerência da autarquia federal".

${ }^{46}$ Ver Barbosa, Denis Borges, Ensaios e estudos de Propriedade Intelectual 2014-2015 Volume II Patentes Edição do Instituto Brasileiro da Propriedade Intelectual. 2015. p. 26.

${ }^{47}$ Consoante o $\S 154$ (b) da Lei de Patentes Americana, há previsão de um dia de prazo para cada dia de prazo de mora por culpa somente do USPTO, respeitado o prazo para interpelação administrativa e ainda, descontando o prazo em razão da desídia do depositante. O $\S 154$ (b) (2) (c) prelaciona que: O período de ajuste do prazo de uma patente nos termos do parágrafo (1) deverá ser reduzido por um período igual ao período de tempo durante o qual o requerente deixou de encetar esforços razoáveis para concluir o processamento do pedido. "[(i) The period of adjustment of the term of a patent under paragraph (1) shall be reduced by a period equal to the period of time during which the applicant failed to engage in reasonable efforts to conclude prosecution of the application." Disponível em https://www.uspto.gov/web/offices/pac/mpep/mpep-9015-appx-l.html\#d0e303482 Acesso em 25 de março de 2018.

${ }^{48}$ Cf. Hoss, Eugenio, op. cit, p. 48.

${ }^{49}$ A exigência de modificação da legislação interna para incluir prorrogação por backlog foi incluída em alguns Acordos Bilaterais de Comércio firmados pelos Estados Unidos com certos países em desenvolvimento, ver
} 
Por outro turno, alguns países incorporam - não o Brasil, um outro tipo de extensão compensatória: uma extensão de proteção exclusiva para os registros sanitários de determinados produtos farmacêuticos, que são submetidos à análise de agências nacionais do gênero de nossa ANVISA. De pronto, ressalte-se que o registro sanitário não possui qualquer correlação ao exame técnico de patentes: "dois institutos distintos, com finalidades diversas $" 50$. Assim, no caso hipotético em que existem dez produtos, onde um deles somente vai para análise sanitária e lá tarda, a prorrogação incidirá no objeto do pedido de registro sanitário. A patente morre, sem que remanesça qualquer privilégio de extensão para os outros nove produtos. Essas extensões sanitárias usualmente se denominam SPC (Supplementary Protection Certificate), cujas siglas em inglês referem-se a Certificado de Proteção Especial. Para o OMPI, a hipótese do SPC aplica-se em que tais patentes podem ser "contempladas" com certificado de extensão, pelo tempo perdido junto aos trâmites do FDA - equivalente à ANVISA nos EUA ${ }^{51}$.

Desse modo, à luz do direito comparado e de precedentes jurisprudenciais ${ }^{52}$, o Brasil não adotou a compensação do "prazo variável" da lei americana, tampouco o instituto

Hoss, Eugenio. ob. cit., p. 48 e CORREA, Carlos M. (2007) op. cit., p. 470. Correa lista os seguintes acordos: Jordânia (2001); Chile (2004) Cingapura (2004); Marrocos (2005). Costa Rica, Dominican Republic, El Salvador, Guatemala, Honduras, Nicaragua (CAFTA) (2004); Bahrain (2004).

${ }^{50}$ [Nota do original]. Ver parecer $\mathrm{n}^{\circ} 337$ da Procuradoria Geral da União brasileira, em 2010, sobre a antiga anuência prévia da ANVISA sobre exames de patentes, cuja competência caberia somente ao INPI. À época, a procuradoria já reconhecia a incompetência da ANVISA para lidar com exames de patentes. Disponível em: file:///C:/Users/Rafaella\%20Dias/Dropbox/tese/Medicamentos/propriedade\%20intelectual/parecer 210 2009_pg f\%20INPI\%20e\%20ANVISA.pdf Acesso em 03 de abril de 2010. Hoje, a situação já está pacificada (vide supra nota 280 )

${ }^{51}$ Para maiores desenvolvimentos, ver BARBosA, Denis Borges, e BARBosa, Pedro Marcos Nunes, Algumas notas à intercessão do SPC e da patente pipeline, in A Propriedade Intelectual no Século XXI, Luemn Juris, 2009, disponível em http://denisbarbosa.addr.com/spc.pdf, acesso em 06 de março de 2018.

${ }^{52}$ Precedentes federais brasileiros confirmam a distinção entre o conceito de SPC e de extensão de patentes. Ver: TRF-2 ${ }^{\mathrm{a}}$ REGIÃO, Apelação em Mandado de Segurança $\mathrm{n}^{\mathrm{o}}$ 2005.51.01.507620-5, $1^{\mathrm{a}}$ Turma Especializada, JC Márcia Helena Nunes, publicado em 10.04.2008, decisão unânime: "[o] "Supplementary Protection Certificate" é um instituto da legislação patentária de alguns países europeus que o concede como compensação pela demora na comercialização de produtos farmacêuticos e afins, em face das exigências lá também existentes de exames pelos órgãos públicos. Tal instituto além de não existir no Brasil, confere uma proteção patentária extra, adicionando um tempo maior do que o que o Brasil adotou. Em várias tratativas de acordos internacionais, nosso país negou-se a concordar em adotar o citado instituto. Não poderia, assim, o Judiciário endossar a prática de tal adoção, contrariando a decisão soberana dos representantes legais no Brasil perante as reuniões internacionais relativas à propriedade industrial"; No mesmo sentido, ver também: TRF - da $2^{\mathrm{a}}$ Região, Apelação Cível $\mathrm{n}^{\mathrm{o}}$ 2001.51.01.524082-6, $1^{\text {a }}$ Turma Especializada, JC Márcia Helena Nunes, publicado em 13.12.2007, decisão unânime: "[a]lém disso, no caso presente, houve seguidos pedidos de extensão de patente, obtidos sucessivamente até se obter a data limite de 03.04.2006 (fls. 363/365), após renúncia de direitos. Trata-se de mecanismo apenas previsto em legislação alienígena, em geral decorrendo de demora nos procedimentos autorizativos da comercialização do medicamento, ou seja, do produto coberto pela patente, sendo aplicação de regra do tipo "TRIPS-PLUS", não incorporada pelo Direito Brasileiro e a cuja adesão, em sede internacional, o Brasil tem reiteradamente se oposto". 
compensatório que abriga o SPC existente em diversos países, logo, todos possuindo fundamentos e consequências diversas do parágrafo único do Artigo 40 da LPI, inclusive, sendo consideradas medidas TRIPS-plus. Desume-se, então, que não é possível afirmar que diversos países também adotaram a extensão legal de patente nos moldes da exceção contida na LPI brasileira, quando na verdade, o que a maioria aplica é o mecanismo SPC que como vimos, se trata de instituto não correlato à dilatação de patente, bem como está previsto em "legislação alienígena" da brasileira, a exemplo de países da EU, como Portugal, França e Espanha $^{53}$.

O que ocorre no direito interno brasileiro é que além do mesmo resguardar os interesses do depositante da patente no parágrafo único do Arts. 40 da LPI com a prorrogação, também permite uma outra garantia retroativa da patente, nos arts. 42 e $44, \S 1^{\circ}$ e $\S 3^{\circ}$ da LPI, que já é concedida independentemente de haver ou não a extensão naquele. Como já dito anteriormente, o art. 42 contempla o direito exclusivo aos inventores. Por sua vez, o art. 44, $\S$ $1^{\circ}$ possui natureza compensatória em favor do titular da patente, no caso de violação da mesma enquanto perdurar a sua validade, vejamos:

Artigo 44: Ao titular da patente é assegurado o direito de obter indenização pela exploração indevida de seu objeto, inclusive em relação à exploração ocorrida entre a data da publicação do pedido e a da concessão da patente.

$\S 1^{\circ}$ : Se o infrator obteve, por qualquer meio, conhecimento do conteúdo do pedido depositado, anteriormente à publicação, contar-se-á o período da exploração indevida para efeito da indenização a partir da data de início da exploração $[\ldots]$

$\S 3^{\circ} \mathrm{O}$ direito de obter indenização por exploração indevida, inclusive com relação ao período anterior à concessão da patente, está limitado ao conteúdo do seu objeto, na forma do art. $41^{54}$.

Ao prever direitos exclusivos ao titular da patente e permitir uma proteção retroativa, os arts. 42 e 44 da LPI consagram a eficácia da patente antes da concessão, inclusive com efeitos econômicos, que não se limite somente ao prazo de vigência da patente ${ }^{55}$. Tal deriva de um

${ }^{53} \mathrm{Cf}$. MEJER Malwina, 25 years of SPC protection for medicinal products in Europe: Insights and challenges, Maio $\quad$ de $2017 . \quad$ Disponivel em file://C:/Users/Rafaella\%20Dias/Dropbox/tese/Medicamentos/propriedade\%20intelectual/SPC\%20EU\%200210 \%2017\%20final\%20Malwina\%20Mejer.pdf Acesso em 03 de maio de 2018.

${ }^{54}$ Vide supra nota 2, art. 44 e ss.

${ }^{55}$ Como já se afirmou, a eficácia econômica de uma patente não se limita ao prazo de vigência da patente. Com efeito, o poder dissuasório de uma patente, em face de seus concorrentes, nasce do momento em que o titular do pedido de patente exerce seu direito de fazer o primeiro depósito no mundo. A partir desse depósito, nasce para o titular o poder de requerer o monopólio em todo e qualquer país onde se reconheça o direito de prioridade ou direito de requerimento ao estrangeiro. Em cada um desses Estados cria-se uma expectativa de direito que desaconselha o investidor prudente de exercer a concorrência com o uso da solução técnica para a qual se pede a 
poder dissuasório que a patente exerce face aos concorrentes, criando uma expectativa de direito que desestimula o investidor a exercer o monopólio e ao mesmo tempo protegendo o depositante do direito de obter indenização por exploração indevida em período anterior à concessão das patentes ${ }^{56}$. Nesse sentido, o já mecionado Estudo britânico (2010) também concluiu que o lapso temporal entre o depósito e a concessão da patente impede a plena eficácia das patentes legítimas e mais: que há um quase-monopólio nesse meio tempo para patentes que não serão e não deveriam ser concedidas, com base no temor causado aos competidores de que ela poderá ser concedida:

\begin{abstract}
Além de dissuadir os depositantes legítimos, o aumento da pendência também impõe custos por ocasionar proteção às patentes pendentes e, portanto, um poder de (quase) monopólio para os depositantes cujas invenções não sejam patenteáveis. Isto pode conduzir a preços mais elevados para os respectivos produtos, já que os concorrentes se sentem desencorajados de entrar no mercado. (...) fomos capazes de estimar o aumento no valor de uma patente pendente devido ao aumento da pendência da patente. Este aumento reflete o fato de que, com a proteção da patente pendente, os depositantes serão capazes de cobrar preços mais altos, pois nenhum concorrente será capaz de entrar no mercado ${ }^{57}$.
\end{abstract}

Essa posição é confirmada pela jurisprudência do Superior Tribunal de Justiça brasileiro (STJ) ${ }^{58}$, que em decisão recentíssima, afirmou que já há compensação conferida pela LPI ao

exclusiva. A ciência da existência desse pedido se dará, na maior parte dos casos, após o período de sigilo que é - em regra - de dezoito meses. Interesses estratégicos podem fazer com que o titular torne público a descrição ou referência do teor do pedido para - exatamente - desincentivar a competição mesmo pelos competidores que têm tecnologias competitivas que possam colidir, ainda que em parte, com o objeto do pedido ${ }^{55}$. Cf. BARBOSA, Denis Borges (2015) op. cit., p. 45 ss.

${ }^{56}$ A Convenção da Patente Europeia dispõe, em seu art. 67, que após a abertura do pedido de patente à inspeção pública, haverá em cada país-membro uma proteção provisória equivalente à patente concedida. Entretanto, o país pode optar, na legislação interna, por apenas assegurar a indenização devida, equivalente à que resultaria da infração da patente concedida. "[a]rticle 67: Rights conferred by a European patent application after publication (1) A European patent application shall, from the date of its publication, provisionally confer upon the applicant the protection provided for by Article 64, in the Contracting States designated in the application". (2) Any Contracting State may prescribe that a European patent application shall not confer such protection as is conferred by Article 64. However, the protection attached to the publication of the European patent application may not be less than that which the laws of the State concerned attach to the compulsory publication of unexamined national patent applications. In any event, each State shall ensure at least that, from the date of publication of a European patent application, the applicant can claim compensation reasonable in the circumstances from any person who has used the invention in that State in circumstances where that person would be liable under national law for infringement of a national patent". Disponível em: http://www.epo.org/law-practice/legal-texts/html/epc/2016/e/ar67.html Acesso em 11 de janeiro de 2018.

57: "As well as deterring legitimate applications, increased pendency also imposes costs through providing patent pending protection and hence (quasi) monopoly power to applicants with non-patentable inventions. This may lead to higher prices for the respective products, as competitors are deterred from entering the market. (...) we are able to estimate the increase in the value of a pending patent due to an increase in patente pendency. This increase reflects the fact that, with pending patent protection, applicants will be able to charge higher prices, as no competitor will be able to enter the market." London Economs, 2010. Vide supra nota 275, p. 64.

58 STJ - RECURSO ESPECIAL No 1.721 .711 - RJ (2017/0261991-0). Relatora MINISTRA NANCY ANDRIGHI. (2018). Disponível em: https://stj.jusbrasil.com.br/jurisprudencia/574624887/recurso-especial-resp1721711-rj-2017-0261991-0/relatorio-e-voto-574624910 Acesso em 05 de maio de 2018.

PIDCC, Aracaju/Se, Ano VII, Volume 12 no 03, p.046 a 081 Out/2018 | www.pidcc.com.br 
depositante da patente: "[i]mporta consignar que a partir da data da publicação do pedido de patente (e não apenas a partir do momento em que a patente é concedida) o depositante já possui tutela legal que lhe garante impedir o uso, por terceiros, do produto ou processo a que se refere seu requerimento, além de indenização por exploração indevida, conforme estipulam os arts. 42 a 44 LPI. Dessa forma, apesar da expedição tardia da carta-patente pelo INPI, a invenção do recorrente, no particular, não esteve, em absoluto, desprovida de amparo jurídico".

Para BARBOSA $(2015)^{59}$, a singularidade da prorrogação de patentes prevista na exceção contida no art. 40 da LPI fica mais evidenciada quando está em cotejo com o art. 44 da mesma lei: “[o] art. 44, seguindo uma tendência das legislações de patente, garante a indenizabilidade das infrações incorridas em período anterior à concessão. Assim, ainda que haja retardo na concessão, o depositante poderá recobrar a lesão de seus interesses jurídicos. Já o art. 40 parágrafo único garante um prazo mínimo de vigência após a concessão. Mas não o faz, porém, cancelando a eficácia retroativa. Somam-se a retroação e a extensão. Com o prazo maior, os concorrentes - que pelas razões econômicas e de fato citadas acima não terão entrado no mercado - ficam proibidos de utilizarem a tecnologia revelada por tempo ainda maior dos que os vinte anos impostos pelo direito internacional".

Tal, nos leva a crer que o legislador proporcionou uma duplicidade de benefícios aos requerentes das patentes: primeiro com um monopólio de fato (Artigos 42 e 44 da LPI) e depois, se concedida a patente, com anos de monopólio extra (parágrafo único, Artigo 40, da LPI). Com efeito, a exceção contida no artigo 40, além de alimentar a demora sistemática do pedido de patentes, "afeta o acesso a medicamentos ao estender monopólios sobre medicamentos essenciais e a compensação não é justificável, porque o atraso no exame das patentes não prejudica o candidato, ao contrário; durante a longa espera, os produtos já estão no mercado e não enfrentam concorrência, pois qualquer rival que arrisque entrar no mercado pode ser forçado a pagar danos retroativos se a patente for concedida" ${ }^{60 / 61}$.

E mais: a parte que pretende obter a aplicação de uma patente (geralmente uma multinacional de um país avançado) terá muito mais a ganhar do que aqueles que buscam

\footnotetext{
${ }^{59}$ BArbosA, Denis Borges. Op., Cit., p. 74 ss.

${ }^{60}$ [Nota do Original] Palavras de Pedro Villardi, coordenador do Grupo de Trabalho de Propriedade Intelectual (GTPI), que é baseado na Associação Brasileira Interdisciplinar de AIDS (Associação Brasiliera Interdisciplinar de Aids Observatório Nacional de Políticas de Aids) (ABIA). Disponivel em: http://www.ipwatch.org/2018/05/18/patent-backlogs-fuel-efforts-extend-pharma-patent-terms-thailand-brazil-aidsactivists-say/ Acesso em 16 de março de 2018.

${ }^{61}$ STJ, 4a Turma, Min. Luis Felipe Salomão, Medida Cautelar Inominada de n ${ }^{\circ}$ 15222, DJ 20.02.2009: “[a] patente, da forma como foi concedida, não é um direito natimorto. Pois a nossa legislação conferiu efeitos retroativos à data do seu depósito, podendo o seu titular promover ações necessárias à defesa do seu direito".
} 
contestar uma patente, por exemplo. STIGLITZ et. al. (2017) ${ }^{62}$ afirmam que: "os processos judiciais para contestar a validade de patentes são dispendiosos e demorados. Se uma empresa tenta derrubar uma patente, o conhecimento incorporado à patente fica aberto para uso, inclusive por concorrentes e o custo em termos de dinheiro e esforço não são apropriados pelo desafiante da patente". Nesse caso, cases paradigmáticos, como a rejeição da patente do medicamento Gleevec pelo Supremo Tribunal da Índia, em 2013, são uma exceção ${ }^{63}$.

Portanto, o Brasil é um dos poucos países a adotar a extensão do prazo de validade de patentes no direito interno ${ }^{64}$; e como vimos, essa extensão é distinta do "prazo variável" de backlog concedido pela legislação americana, bem como da proteção exclusiva para registro sanitário pela SPC de certos produtos farmacêuticos submetidos ao exame de agências nacionais do gênero da nossa ANVISA. Ainda, registre-se que a LPI já resguarda os interesses do depositante de uma patente nos artigos 42 e 44 e que se a prorrogação do prazo de validade de patentes no parágrafo único do art. 40 se apresenta como "compensação" para

${ }^{62}$ Cf. BaKer, D. \& Jeyadev A. \& StiglitZ, J. E. (2017). Inovação, Propriedade Intelectual e Desenvolvimento: Um conjunto melhor de abordagens para o século 21. (Traduzido por James Tibúrcio). accessibsa,. p. 42.

${ }^{63}$ Ver Novartis AG vs Union of India \& Others. Acórdão de 1 de abril de 2013. O Supremo Tribunal da Índia declarou que: "[u]m monopólio é concedido a um particular em troca da invenção sendo tornada pública para que, no final do prazo da patente, a invenção possa pertencer às pessoas em geral que possam ser beneficiadas por ela. Dizer que a cobertura de uma patente pode ir muito além da divulgação, portanto, parece negar a regra fundamental subjacente à concessão de patentes". Disponível em http://judis.nic.in/supremecourt/imgs1.aspx?filename=40212. Acesso em 21 de março de 2018.

${ }^{64}$ Após a assinatura do Acordo TRIPS, os EUA lançaram meios de objetivar que outros países também aderissem à extensão do prazo de validade de patentes em sua legislação interna (medidas TRIPs-plus), através de acordos de livre-comércio de onde se destaca um dos maiores acordos comerciais do mundo: o Acordo de Parceria Trans-pacífico, também referido como TPP (do inglês Trans-Pacific Partnership), que embora tenha como objetivo primário expandir a indústria nos países em desenvolvimento do Pacífico e estimular o comércio entre todos os países signatários, impôs, em seu esboço final, que cada país signatário fizesse "um ajuste necessário" para incluir a extensão do prazo de validade de patentes no ordenamento jurídico interno. O TPP alcançado finalmente em 2015 entre EUA e países com presença comercial significativa na região do pacífico (Chile, Nova Zelândia, Singapura, Brunei, Austrália, Peru, Vietnã, Malásia, México, Canadá e Japão), prevê a opção de extensão de patentes para os países signatários: "[o]s Estados Unidos procuraram incluir a opção de extensão de cinco anos no TPP, o que resultou em algum desacordo entre as outras partes". [...] "O esboço final do TPP exigia que cada signatário fizesse um "ajuste" disponivel para termos de patentes farmacêuticas quando o produto farmacêutico estava sujeito a uma "redução não razoável" do prazo da patente devido ao processo de aprovação de comercialização" [...] "O TPP incorporou disposições do Acordo de Livre Comércio da América do Norte (NAFTA), que permitem que empresas farmacêuticas processem governos que rejeitaram seus pedidos de patentes cada vez mais perenes através de um mecanismo de resolução de disputas entre estados e investidores. Isso significa que o TPP poderia potencialmente incorporar a prática da evergreening farmacêutica no comércio farmacêutico internacional. Isso permitiria que detentores de patentes farmacêuticas solicitassem novas patentes para pequenas alterações em seus produtos existentes, ampliando assim o monopólio das patentes e retardando ainda mais a introdução de genéricos no mercado. O resultado cumulativo dessas mudanças na lei internacional de patentes também pode comprometer um componente crucial do Acordo TRIPS chamada Declaração de Doha, que garantiu nações acesso a medicamentos essenciais". Para maiores desenvolvimentos, cf. STIMAC, Alexander, The Trans-Pacific Partnership: The Death-Knell of Generic Pharmaceuticals? 49 Vand. J. Transnat'l L. 853 (University Law School, Vanderbilt Journal of Transnational Law), 2016, p. 6 ss.

PIDCC, Aracaju/Se, Ano VII, Volume 12 no 03, p.046 a 081 Out/2018 | www.pidcc.com.br 
o titular da patente, provavelmente estamos diante de um benefício bis in idem a favor da big farma em detrimento do interesse público no Brasil.

\subsection{Acesso a medicamentos e a perenização legal}

O consumo de bens e serviços de saúde vem aumentando no Brasil desde 2010, em razão do crescimento e do envelhecimento populacional. De acordo com o IMS Health, estima-se que o mercado farmacêutico brasileiro mundial deverá alcançar em uma década, o $5^{\circ}$ lugar em faturamento mundial, ficando atrás somente de grandes potências como Estados Unidos, China, Japão e Alemanha ${ }^{65 / 66}$. Por sua vez, os gastos com medicamentos representam uma significativa parcela das despesas de saúde das famílias brasileiras (incluindo planos privados) e também das despesas governamentais, respectivamente: $\mathrm{R} \$ 92,5$ bilhões, cerca de $1,5 \%$ do PIB, e 10,9 bilhões, cerca de $0,2 \%$ do PIB $^{67}$.

Subjacente a esse panorama, a indefinição do prazo de monopólio de exploração da propriedade industrial vem provocando lesões negativas a todo o sistema e a própria Constituição, especialmente ao direito à saúde, em razão da obstacularização à norma programática finalística do (art. 196 da $\mathrm{CFB})^{68}$, bem como à ordem econômica constitucional: a livre concorrência art. 170, IV, da CFB e defesa do consumidor arts. $5^{\circ}$, XXXII, e 170, V, da $\mathrm{CFB}^{69}$. Isso ocorre, porque aos consumidores e aos demais interessados na exploração da patente farmacêutica, que não podem prever e programar-se para iniciar a exploração da patente com a entrada de genéricos no mercado, a pendência prolongada, dificulta o acesso a medicamentos pela população, reduz a variedade de produtos e inibe a concorrência ${ }^{70}$.

65 INTERFARMA - Perspectivas do Mercado Farmacêutico para 2018, 05/01/2018 Disponível em https://www.interfarma.org.br/noticias/1494 Acesso em 06 de fevereiro de 2018.

66 Ainda, acresça-se a essa panorama que o Brasil é um dos países que mais arrecada impostos sobre medicamentos ou seja: o consumidor financia seu tratamento terapêutico, através de medicamentos, e ainda paga um dos maiores tributos do mundos. Para maiores desenvolvimentos, ver: INTERFARMA - Associação da Industria Farmacêutica de Pesquisa - Tributos e Medicamentos. $(2012)$ https://www.interfarma.org.br/public/files/biblioteca/17-Livro $\% 20$ Tributos $\% 20 \mathrm{e} \% 20 \mathrm{Medicamentos} \% 20$ \%20site.pdf Acesso em 03 de abril de 2018.

${ }^{67}$ IBGE - Instituto Brasileiro de Geografia e Estatística. Conta-satélite de saúde: Brasil, 2010-2015. Rio de Janeiro: IBGE, 2018.

68 “"[a] saúde é direito de todos e dever do Estado, garantido mediante políticas sociais e econômicas que visem à redução do risco de doença e de outros agravos e ao acesso universal e igualitário às ações e serviços para sua promoção, proteção e recuperação". Ver BRASIL, Constituição da República Brasileira de 1988. Disponível em http://www.planalto.gov.br/ccivil 03/constituicao/constituicaocompilado.htm Acesso em 02 de abril de 2018.

69 “Art. 170. A ordem econômica, fundada na valorização do trabalho humano e na livre iniciativa, tem por fim assegurar a todos existência digna, conforme os ditames da justiça social, observados os seguintes princípios: [...] IV - livre concorrência; V - defesa do consumidor".

${ }^{70}$ Cf. UNITED KINGDOM. Intellectual Property Office. Patent backlogs and mutual recognition. Jan. 2010. Disponível em: http://bit.ly/ukipo002 ou https://www.gov.uk/government/publications/patent-backlogs-andmutual-recognition; Acesso em: 12 maio 2018, p. ix.

PIDCC, Aracaju/Se, Ano VII, Volume 12 no 03, p.046 a 081 Out/2018 | www.pidcc.com.br 
Portanto, o texto constitucional autoriza a intervenção estatal da economia, por meio de regulamentação e regulação de setores econômicos, desde que o exercício de tal prerrogativa esteja ajustado aos princípios e fundamentos da ordem econômica constitucional ${ }^{71}$.

Um estudo elaborado em 2013 pelo Centro de Estudos e Debates Estratégicos da Câmara dos Deputados, intitulado A revisão da Lei de Patentes: inovação em prol da competitividade nacional, concluiu que: "[n]o caso dos produtos farmacêuticos, por exemplo, a concessão de patente dificulta a efetivação das políticas públicas na área da saúde, além de restringir o acesso a tratamento adequado para grande parte da população, em razão dos altos preços cobrados pelo detentor de patentes ${ }^{72}$ ". E a "grande massa" ainda é dependente do sistema público de saúde, inclusive de forma indireta, obtendo medicamentos (geralmente de alto custo) distribuídos pelo governo por intermédio de demanda judicial ${ }^{73}$.

Para atender as finalidades programáticas constitucionais (art. 196 da CFB) por meio das políticas públicas referentes à assistência terapêutica integral farmacêutica (art. $6^{\circ}$ da Lei 8.080/90), o governo brasileiro efetua a compra e distribuição de medicamentos pelo SUS com base no rol da Relação Nacional de Medicamentos Essenciais (Rename) ${ }^{74}$ e, portanto,

71 “'.... De fato, o texto constitucional de 1988 é claro ao autorizar a intervenção estatal na economia, por meio da regulamentação e da regulação de setores econômicos. Entretanto, o exercício de tal prerrogativa deve se ajustar aos princípios e fundamentos da Ordem Econômica, nos termos do art. 170 da Constituição. Assim, a faculdade atribuída ao Estado de criar normas de intervenção estatal na economia (Direito Regulamentar Econômico, da lição de Bernard Chenot e Alberto Venâncio Filho, Droit public économique, Dictionnaire dês Sciences Économiques, 1958, pp. 420-423 e A intervenção do Estado no domínio econômico. O direito econômico no Brasil, 1968, respectivamente) não autoriza a violação ao princípio da livre iniciativa, fundamento da República (art. $1^{\circ}$ ) e da Ordem Econômica (art. 170, caput) [...]” Ver: STF. REXt 422941, Relator(a): Min. CARLOS VELLOSO, DJ 24-03-2006 - Trecho do voto do relator).

${ }^{72} \mathrm{O}$ estudo destina um tópico especial (tópico 4) para tratar da "não extensão do prazo de patentes" e ao final apresenta uma proposta legislativa (o PL 3.944/2012), de autoria da Deputada Jandira Feghali e outros, que propõe a supressão do parágrafo único do artigo 40 da Lei de Patentes. Disponível em: file://C:/Users/Rafaella\%20Dias/Dropbox/tese/revisao lei patentes.pdf Acesso em 03 de janeiro de 2018. Atualmente, o PL 3.944/2012 ainda está em trâmite na Câmara dos Deputados, cujo ultimo andamento da em 09/03/2017. Disponível em http://www.camara.gov.br/proposicoesWeb/fichadetramitacao?idProposicao=545802 Acesso em 03 de janeiro de 2018 .

${ }^{73}$ Cf. DÓRIA, R. Evolução do Padrão de Consumo das Famílias Brasileiras no Período 2003-2009 e Relações com a Distribuição de Renda. [Dissertação de Mestrado] Programa de Pós-Graduação em Economia, PPGE, do Instituto de Economia - UFRJ/Rio de Janeiro. 2013.

74 “[a] Rename é a lista que define os medicamentos que devem atender às necessidades de saúde prioritárias da população brasileira no Sistema Único de Saúde (SUS). A lista de 2017 conta com 869 itens, contra 842 da edição de 2014 [...] A organização da Rename segue orientação da Organização Mundial da Saúde (OMS) que estabelece o material como uma das estratégias para promover o acesso e uso seguro e racional de medicamentos." Ver: MINISTÉRIO DA SAÚDE - Fundo Nacional de Saúde - Ministério da Saúde publica nova lista medicamentos essenciais para o SUS. 28.08.2017. Disponível em: http://portalfns.saude.gov.br/ultimas-noticias/1727-ministerio-da-saude-publica-nova-lista-de-medicamentosessenciais-para-o-sus Acesso em 05 de março de 2018.

PIDCC, Aracaju/Se, Ano VII, Volume 12 no 03, p.046 a 081 Out/2018 | www.pidcc.com.br 
paga os royalties ${ }^{75}$ ao titular da patente farmacêutica, enquanto perdurar a sua vigência. Um levantamento feito até 2016, elaborado pela UFRJ (Universidade Federal do Rio de Janeiro), a pedido da ABIA (Associação Brasileira Interdisciplinar de AIDS, Observatório Nacional de Políticas de AIDS), estimou em 2 bilhões de Reais adicionais o impacto causado ao Ministério da Saúde em compras centralizadas regulares de nove medicamentos essenciais (drogas usadas no tratamento de câncer, Aids e hepatite C) por força de prorrogações da validade de patentes que chegaram a alcançar mais de dez anos ${ }^{76}$. A pesquisa teve por hipótese comparativa a existência de medicamentos genéricos, que com base na Resolução no 2/200477 da Câmara de Regulação do Mercado de Medicamentos da Anvisa, dispõe que o preço de fábrica dos genéricos não poderá ser superior a $65 \%$ do preço dos medicamentos de referência correspondentes. Ou seja, admite-se por pressuposto que esses medicamentos seriam pelo menos $35 \%$ mais baratos na presença de genéricos ${ }^{78}$.

O mesmo estudo ainda comprovou que sete medicamentos sob a égide da dilatação legal e adquiridos por determinação de ordem judicial, entre os anos de 2013 e 2015 (na modalidade de compra por dispensa de licitação em razão de interesse público ${ }^{79}$ ) totalizaram o montante vultoso de $\mathrm{R} \$ 6.802 .191,96$ a mais para o governo brasileiro. Isso ocorre, porque há muitos medicamentos que não são concedidos pelo SUS, ainda que considerados de

\footnotetext{
75 “Royalty é uma palavra de origem inglesa que se refere a uma importância cobrada pelo proprietário de uma patente de produto, processo de produção, marca, entre outros, ou pelo autor de uma obra, para permitir seu uso ou comercialização". Ver: SENADO FEDERAL - Senado Noticias: Royalties. Disponível em: https://www12.senado.leg.br/noticias/glossario-legislativo/royalties Acesso em 02 de outubro de 2018.

76 Paranhos J. Projeto ABIA: extensão de patentes e custos para o SUS. Disponível em: http://www.abifina.org.br/arquivos/download/parecer_ie_ufrj.pdf Acesso em Julho 2016.

77 ANVISA. Câmara de Regulação do Mercado de Medicamentos. Resolução no 2, de 5 de março de 2004. Diário Oficial União $\quad$ da $2004 . \quad$ Disponível http://portal.anvisa.gov.br/documents/374947/2932039/Resolu $\% \mathrm{C} 3 \% \mathrm{~A} 7 \% \mathrm{C} 3 \% \mathrm{~A} 3 \mathrm{o}+\mathrm{n} \% \mathrm{C} 2 \% \mathrm{BA}+2+\mathrm{de}+5+\mathrm{de}+$ mar\%C3\%A7o+de+2004+(PDF).pdf/b6d68347-a134-4465-a2f1-e5ed0cabc747 Acesso em 06 de maio de 2017. ${ }_{78}$ A título de exemplo, é o que ocorre com uma patente associada ao medicamento Fosamprenavir (PI9912156). A mesma foi depositada no INPI em 1999 e concedida em 2016 ou seja, após dezessete anos de processamento. Em tese, teria mais 03 anos até sua patente expirar em 2019, à luz do Acordo TRIPS e do caput 40 da LPI. Graças à prorrogação contida na exceção do parágrafo único do Artigo 40, a patente da droga ganhará mais sete anos de validade, findando em 2023 sua extensão, para completar os dez anos de vigência previstos depois da concessão. Um estudo entabulado em 2017 estimou que os gastos com a aquisição desse medicamento demonstrou um valor médio anual de compras governamentais entre 2011-2014 de R\$40.033.800,00 e que, caso o mesmo tivesse sido fabricado por indústria genérica, o gasto governamental anual no mesmo período teria sido $\mathrm{R} \$ 26.021 .970,00$. A conclusão obtida é que a prorrogação para o medicamento Fosamprenavir provocará um custo "adicional" de pelo menos $\mathrm{R} \$ 99.695 .130,16$ aos cofres públicos brasileiro. Ver JANNUZZI AHL, VASCONCELlos AG. Quanto custa o atraso na concessão de patentes de medicamentos para a saúde no Brasil? Cad. Saúde Pública 2017; 33(8):e00206516, doi: 10.1590/0102-311X00206516, 2017, p. 3.

${ }^{79}$ É reservada à Administração a discricionariedade para decidir, em face das circunstâncias do caso concreto, se dispensa ou não o certame. Até mesmo em presença da hipótese em que a dispensa é autorizada, a Administração Pública pode preferir proceder à licitação, se tal atender superiormente ao interesse público. Para maiores desenvolvimentos, ver: Junior, Jessé Torres Pereira. Comentários à Lei de Licitações e contratações da Administração Pública, São Paulo: Renovar, 2007. p. 290.
} 
imensa "essencialidade" para a saúde pública, como é o caso do medicamento Avastin (bevacizumabe).

\subsubsection{Case study: o medicamento Avastin}

O Avastin é um medicamento oncológico, reinvidicado em quatro pedidos de patente no Brasil (o PI9809388, o PI9809387 e suas divisões PI9816306 e PI9816350, todos da empresa Genentech (representada pela Roche no Brasil), depositados no INPI em 03/04/1998. O primeiro relatório do exame técnico para o pedido PI9809387 foi emitido somente em 22/04/2009, passados já 11 anos do depósito do pedido da patente. As patentes deveriam ser válidas até 2018, porém, após 20 anos do depósito dos pedidos no Brasil, o exame ainda está pendente, de modo que, quando concedidos, gozarão de um prazo de validade de 10 anos contados a partir de sua concessão (de acordo com o parágrafo único do artigo 40 da Lei de patentes). Em alguns países, esses pedidos já foram avaliados e concedidos, tais como Canadá, Estados Unidos, Japão, além de vários países da Europa. Em outros, as patentes para esse mesmo medicamento irão expirar entre os anos 2018 e 2019.

Inequivocamente, a perenização do monopólio de patentes com a mesma importância do medicamento Avastin é um grande desafio para a saúde brasileira, pois tarda a entrada de genéricos no mercado e impede que seja efetivado o interesse social com vistas à garantia à saúde para a maioria dos pacientes com câncer (tais como câncer colorretal, câncer de pulmão, câncer de mama e câncer de células renais). Ainda, ao mesmo tempo que o medicamento possui imensa importância para vários tratamentos oncológicos, possui também um custo elevadíssimo praticado ao alvitre da empresa dententora do monopólio que até os dias atuais não enfrenta concorrência no Brasil, chegando a custar até $\mathrm{R} \$ 6.484,23$ reais, o valor de uma ampola injetável de 400mg do Avastin - Roche ${ }^{80}$.

Considerando que a patente ainda não foi concedida pelo INPI $^{81}$ e que até o momento o medicamento de altíssimo custo não é distribuído pelo SUS, a acessibilidade e variedade do mesmo se encontram reduzidas ao consumidor brasileiro. Tomando por base o estudo que trilhamos no capítulo anterior sobre judicialização da saúde no Brasil, pode-se considerar que

\footnotetext{
${ }^{80}$ Segundo a base de dados K@iros (Disponível em: www.brasil.kairosweb.com , acessado em 02 de junho de 2018) o preço de uma ampola do Avastinß (Roche) injetável $400 \mathrm{mg}$ custa entre: R \$ 5.894,76 e 6.484,23.

${ }^{81} \mathrm{O}$ status legal dos pedidos de patentes no Brasil é verificado no INPI http://www.inpi.gov.br/pedidos-emetapas/faca-busca. Verificação do medicamento Bevacizumabe disponível https://gru.inpi.gov.br/pePI/servlet/PatenteServletController Acesso em 16 de maio de 2018.
} 
o medicamento Avastin está entre os vários medicamentos pleiteados à justiça sob a forma de compelir o governo a concede-lo gratuitamente, à luz de fundamentos constitucionais, tais quais o direito à vida, à saúde e a dignidade da pessoa humana.

Em recentíssima decisão, o Tribunal Regional Federal - $4^{\mathrm{a}}$ Região manteve em grau de recurso a "tutela de urgência ${ }^{82 "}$ concedida pelo juízo a quo, determinando que a União, o Estado e o Municipio (através da responsabilidade solidária) ${ }^{83}$ fornecessem à parte requerente o medicamento Avastin (Bevacizumabe) por tempo indeterminado. Entre os fundamentos arrogados, o Relator entendeu que o STF está firmando jurisprudência no sentido de que há legitimidade constitucional para o controle e intervenção nas políticas públicas nos casos de abusividade e omissão governamental para fazer cumprir o direito à saúde. Transcreva-se, por oportuno, trecho do aresto:

\begin{abstract}
Legitimado está o Judiciário a intervir nas políticas públicas determinando que se cumpra a $\mathrm{CF} / 88$, notadamente o seu art. $196 \mathrm{da} \mathrm{CF} / 88$, preservando sua força normativa não podendo o Estado se furtar à sua obrigação sob alegações vazias e não comprovadas de ausência de recursos para a efetivação dos direitos sociais (" reserva do possível "), tendo em vista a necessidade de se garantir a todos o mínimo existencial, necessário a se viver com dignidade. Em que pese o fornecimento de medicamentos, em alguns casos, exija um alto custo, isso, per si, não pode ser empecilho para o seu fornecimento, como já decidido pelo Min. Gilmar Mendes, na STA ${ }^{\circ} 175 \mathrm{AgR} / \mathrm{CE}$, nos seguintes termos:" o alto custo de um tratamento ou de um medicamento que tem registro na ANVISA não seria suficiente para impedir o seu fornecimento pelo poder público ". Deve-se ter sempre em vista que a vida protegida pela $\mathrm{CF} / 88$ não é qualquer tipo de sobrevivência, mas sim a vida digna, aquela na qual existe efetivamente um cidadão que possui direitos e deveres que devem ser garantidos e respeitados. Dessa forma, não é qualquer tratamento que deve ser custeado pelo Poder Público, mas sim aquele mais adequado e eficaz, capaz de ofertar ao enfermo maior dignidade e menor sofrimento, mesmo que seja de alto custo ${ }^{84}$.
\end{abstract}

\footnotetext{
${ }^{82}$ A tutela de urgência é prevista no Código de Processo Civil brasileiro e considerada satisfativa para evitar um grave dano, conferindo ao autor provisoriamente a garantia imediata das vantagens de direito material para as quais se busca a tutela definitiva. No caso concreto dos medicamentos, a tutela de urgência visa evitar o grave dano da piora do paciente que sem a obtenção a tempo do medicamento pode chegar, inclusive, à morte, caso tenha que aguardar o deslinde do processo. "A antecipação é dos efeitos práticos que seriam gerados com a concessão definitiva da tutela pretendida elo autor e não da tutela jurisdicional em si. Portanto, não se antecipa a tutela constitutiva ou declaratória da mesma forma não se antecipa a tutela condenatória, mas sim os efeitos que essas tutelas geram no plano dos fatos". Para maiores desenvolvimentos, ver: NEves, Daniel Amorim Assumpção. Manual de Direito Civil - volume único. 8ed. - Salvador: Ed. JusPodivm, 2016, p. 439.

${ }^{83}$ De acordo com precedentes jurisprudenciais do STJ: "[é] solidária a responsabilidade pela efetivação do direito à saúde (art. 23, inciso II, da CF), o que implica não apenas na elaboração de políticas públicas e em uma consistente programação orçamentária para tal área, como também em uma atuação integrada entre tais entes, que não se encerra com o mero repasse de verbas". Ver STJ - REsp 1657951 - Ministro MAURO CAMPBELL MARQUES - DJ 03/04/2017.

${ }^{84}$ Ver TRF-4 REGIÃO: AG 50710072220174040000 5071007-22.2017.4.04.0000, Relator SÉRGIO RENATO TEJADA GARCIA, 12.01.2018. Disponível em: https://trf-4.jusbrasil.com.br/jurisprudencia/539165344/agravode-instrumento-ag-50710072220174040000-5071007-2220174040000?ref=topic feed Acesso em 13 de março de 2018.
}

PIDCC, Aracaju/Se, Ano VII, Volume 12 no 03, p.046 a 081 Out/2018 | www.pidcc.com.br 
A decisão supra faz parte do avolumado de ações judiciais no Brasil no que toca o requerimento por via judicial de medicamentos, que na sua maioria, são de alto custo e não constam no rol do Rename, logo, não são distribuídos pelo SUS ${ }^{85}$. A judicialização da saúde para o acesso a medicamentos "camufla" o sucesso no domínio da proteção à saúde, haja vista que a destinação de verbas para cada vencedor dessas ações representa um peso considerável aos cofres públicos e consequentemente a toda a sociedade civil. Nesse sentido, alguns precedentes jurisprudenciais são coerentes ao admitir que: "[n]ão é ônus do Judiciário administrar o SUS [...] Os recursos do SUS são, notoriamente, escassos. Deferir-se, sem qualquer planejamento, benefícios para poucos, ainda que necessários, podem causar danos para muitos, consagrando-se, sem dúvida, injustiça. Sequer pode-se considerar o Judiciário como uma via que possibilite que um paciente possa burlar o fornecimento administrativo de medicamentos, garantindo seu tratamento sem que se leve em consideração a existência de outros na mesma ou em piores circunstância ${ }^{86} . "$

Portanto, a dilatação do prazo de validade de patentes além de macular a livre concorrência, reduz as possibilidades do consumidor adquirir o medicamento por conta própria. Com efeito, vem tornando-se contumaz para uma parcela desses consumidores (na sua maioria pessoas com recursos) provocar o judiciário para a obtenção "indireta" de medicamentos pelo governo, na sua maioria, de alto custo. E embora esses grupos possam lograr êxito no caso concreto, a sociedade como o todo é quem suporta as consequências deletérias causadas pela extensão legal de patentes no ordenamento jurídico brasileiro, pois questões como essas, no entendimento de STIGLITZ (2014) ${ }^{87}$ : “[c]ostumam envolver um

\footnotetext{
${ }^{85} \mathrm{O}$ fornecimento de medicamentos sem que contenha na listagem do SUS faz parte dos Recusos Repetitivos do STJ. Recurso repetitivo, portanto, é aquele que representa um grupo de recursos especiais que tenham teses idênticas, ou seja, que possuam fundamento em idêntica questão de direito". Ver http://www.sti.jus.br/sites/STJ/default/pt BR/Processos/Repetitivos-e-IAC/Saiba-mais/Sobre-Recursos

Repetitivos Acesso em 02 de abril de 2018. "A Primeira Seção do Superior Tribunal de Justiça concluiu o julgamento de recurso repetitivo (REsp 1.657.156), relatado pelo ministro Benedito Gonçalves, que fixa requisitos para que o Poder Judiciário determine o fornecimento de remédios fora da lista do SUS. Os critérios estabelecidos só serão exigidos nos processos judiciais que forem distribuídos a partir desta decisão, sendo eles: 1 - Comprovação, por meio de laudo médico fundamentado e circunstanciado expedido por médico que assiste o paciente, da imprescindibilidade ou necessidade do medicamento, assim como da ineficácia, para o tratamento da moléstia, dos fármacos fornecidos pelo SUS; 2 - Incapacidade financeira do paciente de arcar com o custo do medicamento prescrito; e 3 - Existência de registro do medicamento na Agência Nacional de Vigilância Sanitária (Anvisa)". Cf. REsp 1682973 / RJ RECURSO ESPECIAL 2017/0167357-7, Ministro O G FERNANDES (1139), T2 - SEGUNDA TURMA, DJe 11/06/2018.

${ }^{86}$ Ver TRF4 - Apelação n $5000879-84.2011 .404 .0000$, Relatora Marga Inge Barth Tessler - D.E. 10/04/2011. Disponível em: https://trf-4.jusbrasil.com.br/jurisprudencia/561298920/apelacao-remessa-necessaria-apl50073239420164047005-pr-5007323-9420164047005/inteiro-teor-561298927 Acesso em 05 de abril de 2017.

${ }^{87}$ Cf. STiglitz, Joseph, op., cit., p. 101 e 165.
}

PIDCC, Aracaju/Se, Ano VII, Volume 12 no 03, p.046 a 081 Out/2018 | www.pidcc.com.br 
verdadeiro desperdício de recursos, o qual baixa a produtividade e o bem-estar do país. Distorcem a alocação de recursos e tornam a economia mais fraca".

\section{MEdidAS ALTERNATIVAS À REDUÇÃo do baCKLOG DE PATENTES E À SUPRESSÃO DA PERENIZAÇÃO LEGAL}

No âmbito do Poder Executivo, algumas medidas já estão sendo implementadas no sentido de dirimir o backlog no Brasil. Recentemente, o Ministério da Indústria, Comércio Exterior e Serviços (MDIC) e o INPI propuseram a implementação de um procedimento de deferimento simplificado de pedidos de patente, com vistas a reduzir o significativo backlog de patentes. Uma consulta pública, que visou obter a opinião e sugestões de especialistas e profissionais da área, foi encerrada em 2017, mas a questão continua em análise interna do órgão ${ }^{88}$.

A nível de colaboração internacional, um recentíssimo acordo entre o Brasil e Reino Unido, assinado em março de 2018 durante a $10^{\mathrm{a}}$ reunião do Comitê Econômico e de Comércio Conjunto Reino Unido-Brasil (JETCO, na sigla em inglês), realizado em Londres, teve por objetivo o fomento à celeridade da análise de pedidos de patentes. $\mathrm{O}$ acordo prevê uma colaboração mútua entre o INPI e o UKIPO, através do projeto-piloto Patent Prosecution Highway $(\mathrm{PPH})^{89}$. Nesse modelo, um pedido de patente já concedido no Brasil poderá ter seu exame acelerado no Reino Unido, ao mesmo tempo em que uma solicitação deferida no instituto britânico poderá ser agilizada no INPI ${ }^{90}$. Em média, a proposta no acordo prevê uma

\footnotetext{
${ }^{88}$ BRASIL. MDIC. Propriedade Industrial. INPI. Consulta pública. Aviso de Consulta Pública n 02/2017. Disponível em http://www.inpi.gov.br/menu-servicos/patente/consultas-publicas Acesso em 22 de fevereiro de 2018.

${ }^{89}$ À luz da OMPI, o PCT-PPH permite que os solicitantes de patentes possam fazer uso dos produtos de trabalho de outros escritórios de patentes para acelerar o processamento da análise de patentes na fase nacional. A reutilização de resultados apenas facilita o processo de pedidos de patenes, mas a decisão da concessão permanece ao controle dos escritórios nacionais. O projeto é incluido através de vários acordos bilateriais assinados entre os escritórios de patentes. Vários escritórios em todo o mundo participam do projeto, entre eles: Spanish Patent and Trademark Office, National Institute of Industrial Property (Portugal), United States Patent and Trademark Office, European Patent Office, Japan Patent Office, Japan Patent OfficePara maiores desenvolvimentos, ver: WIPO. PCT-Patent Prosecution Highway Pilot (PCT-PPH and Global PPH). Disponível

em: https://www.google.pt/search?q=wipo+ompi\&oq=wipo+om\&aqs=chrome.1.69i57j015.4219j0j7\&sourceid=chro me\&ie=UTF-8 Acesso em 03 de abril de 2018.

${ }^{90}$ Esse não é o primeiro projeto-piloto do PPH a funcionar no Brasil. Em 2016, cooperação entre Brasil e Estados Unidos no exame de patentes, teve suas regras estabelecidas na Resolução no $154 / 2015$ do INPI. "Nesta fase piloto do PPH, o INPI receberá dos Estados Unidos pedidos apenas da indústria de petróleo e gás, pelo período de dois anos ou até que cada país analise 150 pedidos de patente. Já as empresas brasileiras poderão depositar pedidos de qualquer campo técnico no USPTO”. Ou seja, este ano encerrará a primeira fase do projeto piloto entre o Brasil e EUA. Cf. MDIC. Propriedade Indutrial. INPI. Noticias. Projeto-piloto do PPH já está funcionando. (2016) Disponível em http://www.inpi.gov.br/noticias/inpi-formaliza-regras-e-pph-comeca-afuncionar-dia-11-de-janeiro Acesso em maio de 2018.
}

PIDCC, Aracaju/Se, Ano VII, Volume 12 no 03, p.046 a 081 Out/2018 | www.pidcc.com.br 
redução de cerca de 10 anos (tramitação completa) para nove meses (tempo até o exame após entrada no $\mathrm{PPH}$ ) para campos tecnológicos que ainda serão definidos pelos dois institutos ${ }^{91}$. Todavia, o referido PPH que somente entrará em vigor no terceiro semestre de 2018, é para alguns uma "forma artificial de limpar o acúmulo", na medida que o acordo reduziria a autonomia do Brasil para realizar seus próprios exames de patente, sob seus próprios padrões: "as decisões tomadas em outros países têm abordagens muito diferentes em relação a critérios de exame de patentes" ${ }^{92}$

Uma proposta alternativa para o estímulo ao requerimento de patentes sérias, com vistas à redução do backlog seria o aumento das taxas pelo INPI. Nesse sentido, a Diretora da EPO Alice Brimelow em discurso proferido na Austrália em 2010 propõe que: “[e]u acredito que nossas taxas devam ser estruturadas de modo que somente pedidos de patente meritórios e seriamente redigidos sejam depositados pelos requerentes que então pagarão pelo custo necessário para o trabalho do escritório de patente. Nem mais, nem menos" $" 93$. Os valores arrecadados poderão ser revertidos para o INPI, dentro da lógica da autonomia financeira e administrativa da Autarquia prevista pela LPI no art. 239, objetivando melhorar a infraestrutura, de modo a atingir uma duplicidade de benefícios: menos tempo de análise de patentes e maior qualidade na examinação e processamento das mesmas ${ }^{94}$.

$\mathrm{Na}$ esfera do Poder Legislativo, há dois Projetos de Lei ainda tramitando no Congresso Nacional brasileiro, cuja alteração legal visa a supressão do parágrafo único do art. 40 da LPI. São eles: o PL 3.944/2012 ${ }^{95}$ (que trata especificamente da supressão dentro

\footnotetext{
${ }^{91}$ BRASIL. MDIC. Propriedade Industrial. INPI. Noticias. Brasil e Reino Unido assinam acordo para acelerar exame de patentes. 23 de mar. De 2018. Disponível em http://www.inpi.gov.br/noticias/brasil-e-reino-unidoassinam-acordo-para-acelerar-exame-de-patentes Acesso em 05 de maio de 2018. Ver também em: https://www.uspto.gov/patents-getting-started/international-protection/patent-prosecution-highway/patentprosecution-11 Acesso em 25 de maio de 2018.

${ }^{22}$ Nesse sentido, PEDRO VILLARDI, coordenador do Grupo de Trabalho de Propriedade Intelectual (GTPI), que é baseado na Associação Brasileira Interdisciplinar de AIDS (Associação Brasiliera Interdisciplinar de Aids Observatorio Nacional de Politicas de Aids) (ABIA). Disponível em http://www.ipwatch.org/2018/05/18/patent-backlogs-fuel-efforts-extend-pharma-patent-terms-thailand-brazil-aids-activistssay/ Acesso em 02 de junho de 2018.

93 [Nota do original] BRIMELOW, Alison. Not seeing the woods for the trees: Is the patent system still fit for purpose? The Journal of World Intellectual Property, 2011, n.14.

${ }^{94}$ Uma forma de impedir que patentes mais fracas sejam aceitas, é uma forma de impedir o "evergreening de uma patente existe. Esse posicionamento é defendido por: STIGLITZ, Joseph E. et. al., op. cit. p. 68.

${ }^{95}$ BRASIL. CÂMARA DOS DEPUTADOS. Atividade Legislativa. Projeto de Lei e outras proposições. PL 3944/2012. Brasília-DF. 24.05.2012. Disponível em: http://www.camara.gov.br/proposicoesWeb/fichadetramitacao?idProposicao=545802 Último acesso em $30 \mathrm{de}$ junho de 2018.
}

PIDCC, Aracaju/Se, Ano VII, Volume 12 no 03, p.046 a 081 Out/2018 | www.pidcc.com.br 
da perspectiva dos medicamentos) e 6.968/2017 ${ }^{96}$ (que trata da supressão de modo geral). O já mencionado estudo da revisão da lei de patentes, recomendou a aprovação do PL 3.944/2012, após concluir pela impossibilidade de se estender para além dos 20 anos o período da vigência de uma patente em decorrência de demora em sua concessão. Avaliza que a extensão desse prazo não é razoável e pode ser altamente prejudicial à sociedade. Aclarea também nosso posicionamento, a partir da análise do art. 44 da LPI, de que o inventor já está protegido pelos vinte anos fixados por meio da Lei de Patentes, tendo por base o Acordo TRIPS, a partir da data do depósito do pedido. E que por isso, não haveria justificativa "compensatória" para se estender o prazo de patentes além do prazo vintenário com base no parágrafo 40 da LPI. Ainda, ressalta a recomendação da ONU que países em desenvolvimento não adotem medidas TRIPS-PLUS, considerando, por isso, a dilatação legal como uma perenização nociva aos interesses públicos e ao desenvolvimento tecnológico do país ${ }^{97}$.

Modificações na legislação doméstica são importantes para limitar o excesso de “cercas patentárias", no dizer de Stiglitz et. al. (2017) ${ }^{98}$. Para eles, um bom exemplo de legislação interna no combate ao evergreening, ao método de oposição a patentes fracas e a elevações de padrões de não-obviedade [passo inventivo] é o sistema de patentes na Índia. Os autores acrescentam ainda que: "[s]eja qual for o mecanismo, a possibilidade de um procedimento de avaliação mais rigoroso e maximizador de oportunidades de desafio aos direitos de propriedade intelectual (dentro de limites razoáveis) pode ajudar a mitigar o mal estruturado mecanismo de incentivo atualmente existente". Desse modo, a exemplo da alteração legiferante procedida na Índia, ainda que o objeto seja diverso das PLs em trâmite no Brasil, espera-se que o Poder Legislativo brasileiro consiga alcançar com a supressão do dispositivo atacado, uma maximização de qualidade na legislação doméstica de proteção patentária brasileira dentro de limites razoável almejado.

Finalmente, no Poder Judiciário, duas Ações Diretas de Inconstitucionalidade ${ }^{99}$ foram protocolizadas pela Associação Brasileira das Indústrias de Química Fina, Biotecnologia e

${ }^{96}$ BRASIL. CÂMARA DOS DEPUTADOS. Atividade Legislativa. Projeto de Lei e outras proposições. PL 6.968/2017. Brasília-DF. 20.02.2017. Disponível em: http://www.camara.gov.br/proposicoesWeb/fichadetramitacao?idProposicao=2124058 Último acesso em $30 \mathrm{de}$ junho de 2018.

${ }_{97}$ Vide supra nota 72.

${ }^{98}$ STigLitz, Joseph E. et. al., op. cit. p. 68.

${ }^{99}$ A ação direta de inconstitucionalidade de lei ou de ato normativo federal ou estadual é uma das espécies de controlo abstrato sucessivo concentrado de normas jurídicas por via de ação no ordenamento jurídicoconstitucional do Brasil, a cargo do Supremo Tribunal Federal. Pode ser de iniciativa do Presidente da República, da Mesa do Senado Federal, da Mesa da Câmara dos Deputados, da Mesa da Assembléia Legislativa ou da Câmara Legislativa do Distrito Federal, do Governador do Estado ou do Distrito Federal, do Procurador- 
suas Especialidades (ABIFINA) em 2014, e pelo Procurador-Geral da República em 2016, respectivamente, ADI 5.061 ${ }^{100}$ e ADI 5.529101. As ações visam igualmente extirpar o parágrafo único do artigo 40, da Lei 9.276/1996, tendo em vista a incompatibilidade com o sistema constitucional vigente. Nos argumentos alinhavados destacou-se que a prorrogação além de causar insegurança jurídica, afronta diversos preceitos textuais e principiológicos da Constituição Federal, em especial os dispositivos insertos nos $\operatorname{artigos~}^{\circ}$, IV, $5^{\circ}$, XXIX, XXXIV, LXXVIII, $37^{\circ}$ caput e $\S 6^{\circ}, 170^{\circ}$ caput e seus incisos III, IV e V, além de seu parágrafo único, todos da Carta Magna.

Destaca-se das Ações, o privilégio temporário previsto no art. $5^{\circ}$, XXIX da $\mathrm{CFB}$, como um mandado de otimização outorgado pelo Constituinte que conota a delimitação temporária e previsível da patente desde o exercício da pretensão da tutela (depósito) ${ }^{102}$ ". A proteção patentária, como privilégio obrigatoriamente temporário que é, apresenta-se nas ADIs como exceção à regra geral ao regime constitucional de ampla concorrência e violação ao princípio da livre iniciativa (art. $1^{\circ}$, IV e 170 caput) e que em razão da incerteza do fim da concessão patentária, o art. 40, parágrafo único, afronta o caráter da temporariedade daquele preceito constitucional, bem como a Ordem Econômica. Todavia, para o depositante, a mora acaba sendo benéfica, pois consoante o poder dissuasório contido na pretensão retroativa compensatória (art. 44, da LPI) o titular da patente "não possui grandes interesses na

Geral da República, do Conselho Federal da Ordem dos Advogados do Brasil, do partido político com representação no Congresso Nacional e da confederação sindical ou entidade de classe de âmbito nacional [artigos $102^{\circ}$, I, alínea $a$ ), e $103^{\circ}$, I a IX, da Constituição Federal]. A ADI possui um caráter dúplice, consoante art. 23 da Lei 9.868/99, ao estabelecer que: "efetuado o julgamento, proclamar-se-á a constitucionalidade ou inconstitucionalidade da disposição ou da norma impugnada se num ou noutro sentido tiverem manifestado pelo menos seis ministros, quer se trate de ação direta de inconstitucionalidade ou de ação declaratória de constitucionalidade". Os efeitos da decisão pela inconstitucionalidade ou constitucionalidade são gerais (erga omnes), retroativos (ex-tunc) e vinculantes (obrigatórios) em relação aos órgãos do Poder Judiciário e à Administração Pública federal, estadual ou municipal. Em relação ao legislador, os efeitos vinculantes se manifestam no impedimento da edição de novas normas com idêntico conteúdo aos das anteriormente declaradas inconstitucionais ou de novas normas que convalidem os efeitos da norma declarada inconstitucional ou que anulem os efeitos da decisão do Supremo Tribunal Federal. Cf. MoraES, A.D. (2017). Direito Constitucional, $33^{\mathrm{a}}$ ed., São Paulo, Atlas, 2017. p. 265-277.

100 STF. ADI/5.061. Disponível em: http://www.stf.jus.br/portal/processo/verProcessoAndamento.asp?incidente=4490434 Último acesso em $02 \mathrm{de}$ jul. de 2018.

${ }_{101} \quad$ STF. ADI $/ 5529 . \quad$ Disponível em:

http://www.stf.jus.br/portal/geral/verPdfPaginado.asp?id=10987526\&tipo=TP\&descricao=ADI\%2F5529 Último acesso em 02 de jul. de 2018.

102 "A proteção jurídica concedida ao titular da patente ou do certificado, após o registro em órgão competente, defere ao titular direito exclusivo ao seu uso, direito monopolístico, porém temporário. A propriedade industrial, na verdade, acentua o característico de temporariedade" REQUIÃo, Rubens. Curso de Direito Comercial. 31 Edição, São Paulo: Editora Saraiva, 2012, p. 185. 
celeridade ou na normalidade do trâmite, o que pode ser constatado pela existência de um grande número de emendas e modificações dos pedidos".

No que pertine ao INPI, as ADIs ressaltam a importância da eficiência da administração, não somente como "uma exegese de soft law", mas como uma "verdadeira manifestação imediata e irradiante ao Estado". Nesse sentido, extrai-se da ADI 5.061, os itens 5.3 e $5.4^{103}$ : “[n]o tocante ao parágrafo único, do artigo 40, da Lei 9.279/96, não atende ao mandado de otimização da eficiência ${ }^{104}$ a possibilidade de meramente se diferir o prazo do domínio público de uma patente, após a ocorrência de mora na sede do processo administrativo no INPI. Em verdade, o prazo dilatório serve como um lenitivo (desproporcional, não razoável, e inconstitucional) a afastar o cerne do problema do hiato temporal crescente nas decisões administrativas sobre patentes". Assim, a inconstitucionalidade da dilatação do prazo de patente é reconhecida também ante o caput do art. 37 da $\mathrm{CFB}^{105}$ e do art. 5०, LXXVIII, da CFB: “[a] todos, no âmbito judicial e administrativo, são assegurados a razoável duração do processo e os meios que garantam a celeridade de sua tramitação".

Dado o exposto, em suma as medidas alternativas acima comungam da mesma problematização: há um uso desmesurado da prorrogação como "salvaguarda" da ineficiência administrativa e então, a previsão do parágrafo único do artigo 40 da LPI apresenta-se como um beneplácito para a ilegítima leniência estatal. Tal situação não é uma exigência do Acordo TRIPS e em si é incompatível com a constituição e por isso mesmo: com o privilégio temporário nela contida, a função social da propriedade, a eficiência administrativa, a segurança jurídica, o desenvolvimento tecnológico e econômico do país e especialmente na acessibilidade a medicamentos, como corolário do direito à saúde. E a realidade corrobora com os fatos.

\footnotetext{
103 STF. Petição inicial. Disponivel em: http://redir.stf.jus.br/paginadorpub/paginador.jsp?docTP=TP\&docID=4817264\&prcID=4490434\&ad=s\# Último acesso em 02 de junho de 2018.

104 "O núcleo do princípio é a procura de produtividade e economicidade e, o que é mais importante, a exigência de reduzir os desperdícios de dinheiro público, o que impõe a execução dos serviços públicos com presteza, perfeição e rendimento funcional (...) Note-se que a nova norma constitucional não se cinge aos processos judiciais, mas também àqueles que tramitam na via administrativa, muitos destes, da mesma forma, objeto de irritante lentidão". Cf. FILHO, José dos Santos Carvalho. Manual de Direito Administrativo. 24a Edição, Rio de Janeiro: Lumen Juris, 2011, p. 27.

105 “Art. 37. A administração pública direta e indireta de qualquer dos Poderes da União, dos Estados, do Distrito Federal e dos Municípios obedecerá aos princípios de legalidade, impessoalidade, moralidade, publicidade e eficiência" [...] $\S 6^{\circ}$ : As pessoas jurídicas de direito público e as de direito privado prestadoras de serviços públicos responderão pelos danos que seus agentes, nessa qualidade, causarem a terceiros, assegurado o direito de regresso contra o responsável nos casos de dolo ou culpa. Ver: BRASIL. Constituição Federal de 1988. Promulgada em 5 de outubro de 1988. Disponível em http://www.planalto.gov.br/ccivil 03/constituicao/constituicaocompilado.htm Acesso em 11 de março de 2018.
} 
A esse despeito, a Fundação Oswaldo Cruz (FIOCRUZ), que recebe subsídios do governo brasileiro para promover a saúde e desenvolvimento social, com projetos de P\&D em medicamentos de referência, destacando-se como um dos principais centros de pesquisas de doenças tropicais no Brasil, anunciou muito recentemente um corte orçamentário de $\mathrm{R} \$ 5,2$ milhões em 2018 e o cancelamento de R\$ 135 milhões no Programa Fortalecimento do Sistema Único de Saúde (SUS), este último, através da Medida Provisória 839. Os cortes já são comuns há alguns anos para a Fundação, o que é deletério para o direito à saúde, através do enfraquecimento de incentivo às políticas públicas, bem como ao desenvolvimento $\mathrm{P} \& \mathrm{D}$ de medicamentos pioneiros no país ${ }^{106}$.

E então, entendemos que o impacto econômico e social causados pela leniência da administração, alimentada pelo uso arbitrário da perenização legal, é uma sangria que resvala negativamente para o próprio setor da saúde, quando vimos, a exemplo do que está a ocorrer com a FIOCRUZ, que a sociedade civil brasileira quem arca com o ônus da ineficiência administrativa e legiferante causados pela extensão do prazo de validade de patentes farmacêuticas. E por não poder custear ela mesma a compra de determinados medicamentos, que ainda estão sob o manto do monopólio extensivo de patentes, recorre ao judiciário brasileiro corriqueiramente para obtenção indireta dos mesmos pelo governo.

\section{CONCLUSÃO}

Vê-se que o direito social à saúde é um direito humano fundamental contido na generalidade dos direitos fundamentais constitucionais nacionais, incluindo o brasileiro. Contudo, não raras são as divergências existentes no modus de realização do direito à saúde pelos Estados. Nesse particular, a saúde no Brasil vem enfrentando questões delicadas, sobretudo no que diz respeito o acesso a medicamentos. Embora haja um lastro de políticas públicas no desiderato das normas programáticas finalísticas sobre a saúde, contidas na constituição federal brasileira de 1988, há algumas incoerências normativas e políticas encontradas no plano infraconstitucional que acabam por fragilizar a concretização do direito à saúde a médio e longo prazo.

\footnotetext{
106 BRASIL. Fundação Oswaldo Cruz - FIOCRUZ. Fiocruz avalia consequências de corte orçamentário. 05.06.2018. Disponível em https://portal.fiocruz.br/noticia/fiocruz-avalia-consequencias-de-corte-orcamentario Acesso em 15 de junho de 2018.
}

PIDCC, Aracaju/Se, Ano VII, Volume 12 no 03, p.046 a 081 Out/2018 | www.pidcc.com.br 
A esse despeito, à revelia da disponibilidade de recursos materiais e humanos sob a averiguação prévia orçamentária, vimos que o poder judiciário de há muito no Brasil vem arrogando uma legitimidade constitucional para o controle e intervenção nas políticas públicas nos casos em que considera o governo omisso à concretização da saúde para o fornecimento de medicamentos não distribuídos por meio do SUS. De revés, a coesão social é afetada na medida em que políticas públicas para o próprio setor, de caráter universal, são desprivilegiadas em razão do desvio forçado de verbas não negligenciáveis para conter a "sangria" dessas demandas judiciais.

Subjacente a esse panorama verifica-se a inconsistência de subsistemas, cuja articulação contribui para a não mitigação da então "judicialização" da saúde. É o caso do prazo de validade da proteção intelectual patentária inserido no ordenamento jurídico brasileiro e medicamentos de referência diante de medicamentos genéricos. Há em causa um conflito entre duas dimensões essenciais do direito à saúde. Uma que se destaca pela inovação e desenvolvimento de medicamentos pioneiros, cujo objetivo é a descoberta de entidades químicas para suprir as carências e emergências sanitárias a nível global, com o monopólio temporário através de patentes, ao passo que a outra privilegia a acessibilidade a medicamentos mais baratos, sobretudo a países em desenvolvimento que possuem pouca ou nenhuma estrutura de investigação tecnológica farmacêutica.

Com a adoção da Lei de propriedade industrial 9.276/1996 que veio na sequência da incorporação do Acordo TRIPS, o Brasil proporcionou aos titulares de patentes um beneplácito a maior com a extensão do prazo de validade de patentes de no mínimo 10 anos a mais em caso de atraso na concessão da mesma pelo INPI (parágrafo único, art. 40 da Lei 9.276/1996). Como vimos, o atraso no exame e processamento das patentes se dá com o fenômeno conhecido como backlog de patentes, cuja leniência pela administração é alimentada pela dita dilatação legal. A regra transformou-se em exceção e hoje em dia quase a totalidade das patentes concedidas no Brasil estão contempladas com a generosa extensão no prazo de sua validade.

Pudemos destacar que a perenização legal das patentes possui uma singularidade que fica ainda mais evidenciada quando posta em cotejo com outros artigos da mesma lei, os quais já preveem providência jurídica indenizatória, desde a data da publicação do pedido de patente, em caso de infrações incorridas por terceiros em período anterior à concessão (art. 42 e 44 da Lei 9.276/1996). Logo, somam-se a retroação (monopólio de fato) e a extensão (monopólio de direito) desumindo-se com isso que provavelmente estamos diante de um benefício bis in idem a favor da big farma em detrimento do interesse público no Brasil, quer PIDCC, Aracaju/Se, Ano VII, Volume 12 no 03, p.046 a 081 Out/2018 | www.pidcc.com.br 
pelo poder dissuasório desses artigos, quer pelo dispêndio e demora que levam os processos que contestam a validade de uma patente, por exemplo.

E então, com a impossibilidade da inserção de alguns medicamentos genéricos no mercado, os efeitos da famigerada prorrogação no prazo de validade de patentes para o Brasil já são em números um deletério impacto a seus cofres públicos. Para compras centralizadas regulares de nove medicamentos de referência e essenciais, um estudo revelou que até 2016, o Ministério da Saúde desembolsou 2 bilhões de reais a mais. Para sete medicamentos adquiridos por determinação de ordem judicial, o valor superou a cifra de 6 bilhões de reais somente entre os anos de 2013 e 2015. Esses valores estão refletidos na quantidade absurda de processos judiciais em trâmite na área da saúde até o ano de 2017 ${ }^{107}$ : 1.346.931, onde o pedido de fornecimento de medicamento pelo SUS se destaca como o campeão de litígio, com 312.147 de ações ainda em curso.

Portanto, não há como negar que a extensão do prazo de validade de patentes é deletéria aos cofres públicos e por consequência a toda a sociedade civil. Os desvios forçados dessas verbas e de compras regulares, pelo governo, de medicamentos que já deveriam estar sob o domínio público são, de revés, nocivos à própria concretização da saúde no Brasil. E comprova essa circunstância na hipótese apresentada dos reiterados cortes orçamentários pelo governo à Fundação Oswaldo Cruz (FIOCRUZ): um dos maiores centros de pesquisa à saúde e desenvolvimento social em medicamentos de referência com subsídios do governo brasileiro.

Os avanços sobre o tema no Brasil ainda estão resilientes sendo importante, desde já, salientar o valor acrescentado em medidas que estão sendo tomadas nesse desiderato. É o caso da cooperação internacional no que toca o backlog de patentes, a exemplo do recentíssimo acordo entre Brasil e Reino Unido com vistas à redução do tempo de concessão de patentes com o projeto-piloto de Patent Prosecution Highway (PPH) que somente entrará em vigor no terceiro semestre de 2018. Finalmente, o parágrafo único do art. 40 da Lei 9.279/1996 é objeto legal questionável pelos Três Poderes no Brasil que comungam da mesma

${ }^{107}$ BRASIL. Conselho Nacional de Justiça (CNJ). 13 edição do Relatório Justiça em Números do Conselho Nacional de Justiça, divulgada no início de Setembro de 2017. [j]udicialização da Saúde (de natureza cível, não criminal), considerando os processos ajuizados até $31 / 12 / 2016$ e em trâmite no $1^{\circ}$ grau, no $2^{\circ}$ grau, nos Juizados Especiais, no Superior Tribunal de Justiça, nas Turmas Recursais e nas Turmas Regionais de Uniformização, totalizando na vultosa soma de 1.346.931 (um milhão trezentos e quarenta e seis mil novecentos e trinta e um) de processos judiciais no setor da saúde Justiça em números 2017: ano-base 2016/Conselho Nacional de Justiça Brasília: CNJ, 2017. Disponível em http://www.cnj.jus.br/programas-e-acoes/pj-justica-em-numeros . Acesso em 17 de abril de 2017. 
preocupação: há um uso desmesurado da prorrogação como "salvaguarda" da ineficiência administrativa. Logo, a mesma se apresenta como um beneplácito para a ilegítima leniência estatal.

E então, a sociedade civil brasileira quem arca com o ônus da ineficiência administrativa e legiferante causados pela extensão do prazo de validade de patentes farmacêuticas. E por não poder custear ela mesma a compra de determinados medicamentos, que ainda estão sob o manto do monopólio extensivo de patentes, recorre ao judiciário brasileiro corriqueiramente para obtenção indireta dos mesmos pelo governo.

\section{REFERÊNCIAS}

Aввотт, Alison. Pressured staff 'lose faith'in patent quality. Nature: International Weekly Journal of Science, p. 429-493, 2004

BAKer, D. \& Jeyadev A. \& Stiglitz, J. E. (2017). Inovação, Propriedade Intelectual e Desenvolvimento: Um conjunto melhor de abordagens para o século 21. (Traduzido por James Tibúrcio). accessibsa,. p. 42

BArbosa, Denis Borges. A propriedade intelectual no século XXI: estudos de Direito. Rio de Janeiro: Lumen Juris, 2009, p. 663

Uma introdução à propriedade intelectual, 2a. Edição, Lumen Juris, 2003, p. 442.

BARROS, Carla Eugenia Caldas. Manual de Direito da Propriedade Intelectual, Evocati: Aracaju, 2007. . Aperfeiçoamento e Dependência em patentes, Lumen Juris: rio de Janeiro, 2004.

Basso, Maristela. Comentário ao art. 5, XXIX. in: CAnotilho, J.J. Gomes; Mendes, Gilmar F.; SARLET, Ingo W.; STRECK, Lenio L.(coords.). Comentários à Constituição do Brasil. São Paulo: Saraiva/Almedina, 2013, p. 335

BRIMElow, Alison. Not seeing the woods for the trees: Is the patent system still fit for purpose? The Journal of World Intellectual Property, 2011, n.14

Canotilho, J.J. Gomes; Mendes, Gilmar F.; Sarlet, Ingo W.; Streck, Lenio L.(coords.). Comentários à Constituição do Brasil. São Paulo: Saraiva/Almedina, 2013, p. 335

Cerqueira, João da Gama. Tratado da Propriedade Industrial, $3^{\mathrm{a}}$. Edição, anotado por Newton Silveira e Denis Borges Barbosa, Lumen Juris, 2010, vol. II, no. 159

DÓRIA, R. Evolução do Padrão de Consumo das Famílias Brasileiras no Período 2003-2009 e Relações com a Distribuição de Renda. [Dissertação de Mestrado] Programa de PósGraduação em Economia, PPGE, do Instituto de Economia - UFRJ/Rio de Janeiro. 2013

Filho, José dos Santos Carvalho. Manual de Direito Administrativo. 24a Edição, Rio de Janeiro: Lumen Juris, 2011, p. 27

Gonçalves, Luís Manuel Couto, Manual de Direito Industrial: Patentes; Desenhos ou Modelos; Marcas; Concorrência Desleal, $2^{\mathrm{a}}$ ed., Coimbra, Almedina, 2008, p. 27 
Hoss, E. (2012). Delays in Patent Examination and their implications under the TRIPS Agreement. Munich Intellectual Property Law Center. MIPLC Master Thesis Series (2010/11), 2012. p. 12

JANNUZZI AHL, VASCONCELlos AG. Quanto custa o atraso na concessão de patentes de medicamentos para a saúde no Brasil? Cad. Saúde Pública 2017; 33(8):e00206516, doi: 10.1590/0102-311X00206516, 2017, p. 3

Um estudo sobre a concessão de patentes de medicamentos no Brasil e suas implicações para a continuidade do êxito na política de medicamentos genéricos. In: Anais do XV Congresso Latino-americano de Gestão Tecnológica. Lisboa: Centro de Estudos em Inovação, Tecnologia e Políticas de Desenvolvimento; 2013. p. 3198-214

Junior, Jessé Torres Pereira. Comentários à Lei de Licitações e contratações da Administração Pública, São Paulo: Renovar, 2007. p. 290

JÚNIOR, Sílvio Sobral Garcez e MoreIRA, Jane de Jesus da Silveira, O backlog de patentes no Brasil: o direito à razoável duração do procedimento administrativo. REVISTA DIREITO GV | SÃO PAULO | V. 13 N. 1 | 171-203 | JAN-ABR 2017. p. 173

KweITEL, J. \& ReIS, R. (2007) A primeira licença compulsória de medicamento na América Latina. International Centre for Trade and Sustainable Development - ICTSD. Pontes, v. 3, (3), junho de 2007

KING, John L. Patent examination procedures and patent quality. In: COHEN, W. M., Merrill, S. A. (Eds). Patents in Knowledge-Based Economy.Washington: National Academies Press, 2003

LABRUNIE, Jacques. Direito de patentes: condições legais de obtenção e nulidades. Barueri, 2006, p. 24

Moraes, A.D. (2017). Direito Constitucional, 33ª ed., São Paulo, Atlas, 2017. p. 265-277

Marques, João Paulo Remédio (II), Medicamentos Versus Patentes - Estudos de Propriedade Industrial, $1^{\text {a }}$ ed., Coimbra, Coimbra Editora, 2008

MitrA-KAHN, Benjamim et al. Patent backlogs, inventories, and pendency: an international framework. Reino Unido: Escritório de Propriedade Intelectual, 2013. p. 134

Neves, Daniel Amorim Assumpção. Manual de Direito Civil - volume único. 8ed. Salvador: Ed. JusPodivm, 2016, p. 439

REQuião, Rubens. Curso de Direito Comercial. 31ª Edição, São Paulo: Editora Saraiva, 2012, p. 185

Rotsch, Thomas. Criminal Compliance. In: Zeitschrift für Internationale Strafrechtsdogmatik. Ausgabe 10/2010, 5. Jahrgang, P. 614 e ss

SAMPAIO, Gilberto, Borchiver, Suzana. Critérios para avaliação dos sistemas patentários, Revista da ABPI, Ro de Janeiro. jan.fev. 2009. p.30-41

SARLET, Ingo Wolgang e SAAVEDRA, Giovani Agostini - Judicialização, Reserva do Possível e Compliance na Área da Saúde -, R. Dir. Gar. Fund, Vitória, v. 18, n.1, 2017, p. 257 282 
Silva, José Afonso da. Comentário contextual à Constituição. 7. ed. São Paulo: Malheiros, 2010, p. 127

Stimac, A. (2016). The Trans-Pacific Partnership: The Death-Knell of Generic Pharmaceuticals? 49 Vand. J. Transnat'l L. 853 (University Law School, Vanderbilt Journal of Transnational Law), 2016, p. 6 